Case Report

\title{
Towards Smart Florianópolis: What Does It Take to Transform a Tourist Island into an Innovation Capital?
}

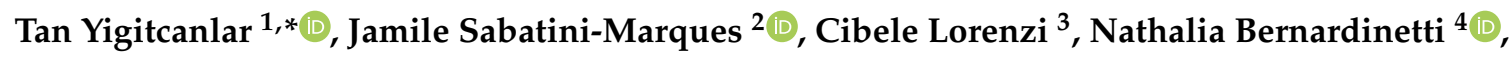 \\ Tatiana Schreiner ${ }^{2}\left(\mathbb{D}\right.$, Ana Fachinelli ${ }^{5}$ and Tatiana Wittmann ${ }^{2}(\mathbb{D}$ \\ 1 School of Civil Engineering and Built Environment, Queensland University of Technology, 2 George Street, \\ Brisbane, QLD 4000, Australia \\ 2 Department of Engineering and Knowledge Management, Federal University of Santa Catarina, \\ Campus Universitario, Trindade, Florianopolis, SC 88040-900, Brazil; jamile@labchis.com (J.S.-M.); \\ tati@labchis.com (T.S.); tatianaw@labchis.com (T.W.) \\ 3 Prefeitura Municipal de Florianópolis, Rua Tenente Silveira, 60, Centro, \\ Florianópolis, SC 88010-102, Brazil; cibele@pmf.sc.gov.br \\ 4 Senac Santa Catarina, Rua Felipe Schmidt, 785, Andar, Centro, Florianópolis, SC 88010-002, Brazil; \\ nathalia.bernardinetti@sc.senac.br \\ 5 Department of Communication, University of Caxias do Sul, Rua Francisco Getulio Vargas 1130, \\ Petrópolis, Caxias do Sul, RS 95070-650, Brazil; acfachin@ucs.br \\ * Correspondence: tan.yigitcanlar@qut.edu.au; Tel.: +61-7-3138-2418
}

Received: 7 October 2018; Accepted: 21 November 2018; Published: 23 November 2018

\begin{abstract}
During the last several decades, the diversification of economic activities has become a paramount policy for nations and cities with heavy dependence on a single economic driver. Particularly island economies, relying mainly on tourism income, are among the most vulnerable ones to the shocks of global financial crises. In the recent years, some of these tourist islands had attempts to diversify their economic activities by moving towards a knowledge and innovation economy. This paper places one of these islands-Florianópolis, the capital city of the Brazilian state of Santa Catarina - under the microscope to address the question of 'what it takes to transform a tourist island into an innovation capital'. In order to tackle this question, the study examines economic, social, spatial, and governance conditions and performances, along with the plans and processes of Florianópolis in moving towards an internationally recognized smart innovation island. The methodologic approach includes systematic review of the literature and qualitative analysis of the key development domains of Florianópolis through the lens of knowledge-based urban development. The results of this study provide insights into how to transform a resource-based economy into a knowledge-based one-by disclosing the transition journey of Florianópolis, including progress, challenges, and the new path creation processes. The findings are particularly useful for tourist islands that are aiming for an aspiring knowledge-based urban development and smart city transformation.
\end{abstract}

Keywords: tourist island; innovation hub; knowledge-based urban development; knowledge and innovation economy; smart city; urban branding; urban policy; economic resilience; Florianópolis; Brazil

\section{Introduction}

Today, in our highly globalized capitalist world, economic resilience has become an exceedingly critical issue not only for the economies of nations, but also for the regional and local economies [1]. Particularly, urban locations with a single-dominant economic sector and specific environmental 
sensitivities are the ones more vulnerable to the impacts of global financial crises [2-4]. Island territories are among those vulnerable locations-where tourism, in general, is the central economic activity, and high environmental sensitivities exist unexceptionally in all of them [5]. In other words, these islands, in general, pose the risk of high environmental vulnerabilities and economic dependencies [6].

For many tourist islands, the diversification of economic activities from tourism and service sectors to knowledge and innovation economy sectors have been a top government policy priority $[7,8]$. To name a few, Canary Islands, Cyprus, Florianópolis, Hawaii, Malta, and Puerto Rico are among these island territories. The rationale behind the diversification efforts is two-fold. Firstly, tourism has a tremendous externality on the environment and natural resources, and is not a sustainable economic activity in the long-run [9]. Secondly, knowledge and innovation economy activities produce higher value-addition with lesser environmental impact, and an upskilled workforce makes the economy more resilient to the prospective global financial crises [10,11].

Many island territories around the globe have been focusing on diversifying their mostly tourism-driven economies with knowledge and innovation economy sectors by adopting new development paradigms [12-14]. Knowledge-based urban development, and smart and sustainable urbanism are the most prominent paradigms considered for such adoption $[15,16]$. While there are specific differences between these two paradigms, their most common targets include: (a) searching for ways to achieve urban sustainability, and; (b) utilizing knowledge and technology to foster and/or attract innovative industries, businesses, and services [17-21]. This case report focuses on revealing the challenges confronted during the mostly organically emerging new pathway of Florianópolis. This pathway aspires to achieve prosperous knowledge-based urban development, and smart city transformation. With the main research question of 'What does it take to transform a tourist island into an innovation capital?' in mind, this study aims to examine economic, social, spatial, and governance conditions, and plans and processes of Florianópolis in moving towards an internationally recognized smart innovation island. In order to achieve the aim and addressing the research question, this case report profiles Florianópolis by exploring the knowledge-based urban development [22] conditions and performance, along with the plans and processes that support or hinder its transformation into a smart innovation island.

Following this brief introduction in Section 1 of the paper, the research design, methodologic approach, and the case study city context are introduced in Section 2. Next, in Section 3, the results of the qualitative study are presented under five sub-sections- the first four of them shedding light on the performance of Florianópolis in each of the knowledge-based urban development domains, and the last one revealing the knowledge-based urban development progress and challenges of the city. Lastly, Section 4 concludes the paper by highlighting the key findings, and concisely discussing their implications for the case study city Florianópolis and beyond.

\section{Materials and Methods}

\subsection{Research Design and Methodology}

This research applied a case study method for empirical investigation. The method was considered appropriate for this research, because it allows defining the topic more broadly (to explore what it takes to transform a tourist island into an innovation capital, or what it takes to transform a resource-based economy into a knowledge-based one) by considering contextual issues in the case, and relying on multiple sources of evidence [23]. The two most common methods of case study research include an inductive approach based on the grounded theory [24], and a deductive or testing approach [23]. The basic difference between these approaches is that while the grounded theory relies on data to generate new theories-there is no initial preconceived framework of concepts and hypotheses-the other approach develops a theory at the beginning of the research and focuses on testing and validating the theory in case settings. Another method proposed by Eisenhardt [25] lies in-between these two approaches that is inductive, but there are elements that follow a more 
planned approach. This research applies both the grounded theory and deductive approaches in a complementary way. In this study, the grounded theory approach was utilized in terms of a literature review to understand how the transformation took place in the selected case study by adopting a knowledge-based urban development perspective [26,27]. In contrast, this research also applied the deductive approach to test the perceptions of key actors on the opportunities and challenges the city faces today. This is accompanied by the likely solutions to the encountered or forthcoming major challenges.

\subsection{Case Study Context: Florianópolis in a Nutshell}

Florianópolis was selected as the case study to satisfy the replication logic of the deductive approach-commencing with generalizations and seeking to see if these generalizations apply to specific instances [28]. The reasons for the selection of the case city context include: (a) being a vibrant emerging economy city context with many developmental opportunities and also numerous challenges [29,30]; (b) achieving noteworthy progress in boosting its research, development, and innovation capabilities, despite being a mainly tourism-based economy [31]; (c) showing the signs of the Dutch disease-an increase in the development of the tourism sector and consequential decline in natural qualities-starting to impact the city in similar ways to the other tourist island destinations [32]; and (d) generated insights from the case investigation potentially being useful for other tourist cities or islands with similar local characteristics and policy ambitions.

The case study city, Florianópolis, is the state capital of Santa Catarina and one of the most developed cities in Brazil—a developing country that became an emerging market economy during the last decades [33]. The city is composed of a main island ( $97 \%$ of the territory), connected to the mainland by bridges, a small continental part, and surrounding uninhabited islands, as shown in Figure 1. The city contains $436.5 \mathrm{~km}^{2}$ land and 453,285 inhabitants, while the metropolitan area has $1,096,476$ people [34]. Florianópolis is a city with the third highest human development index score across all capital cities in Brazil (0.847), making it one of the most livable and safest cities in the nation [35].

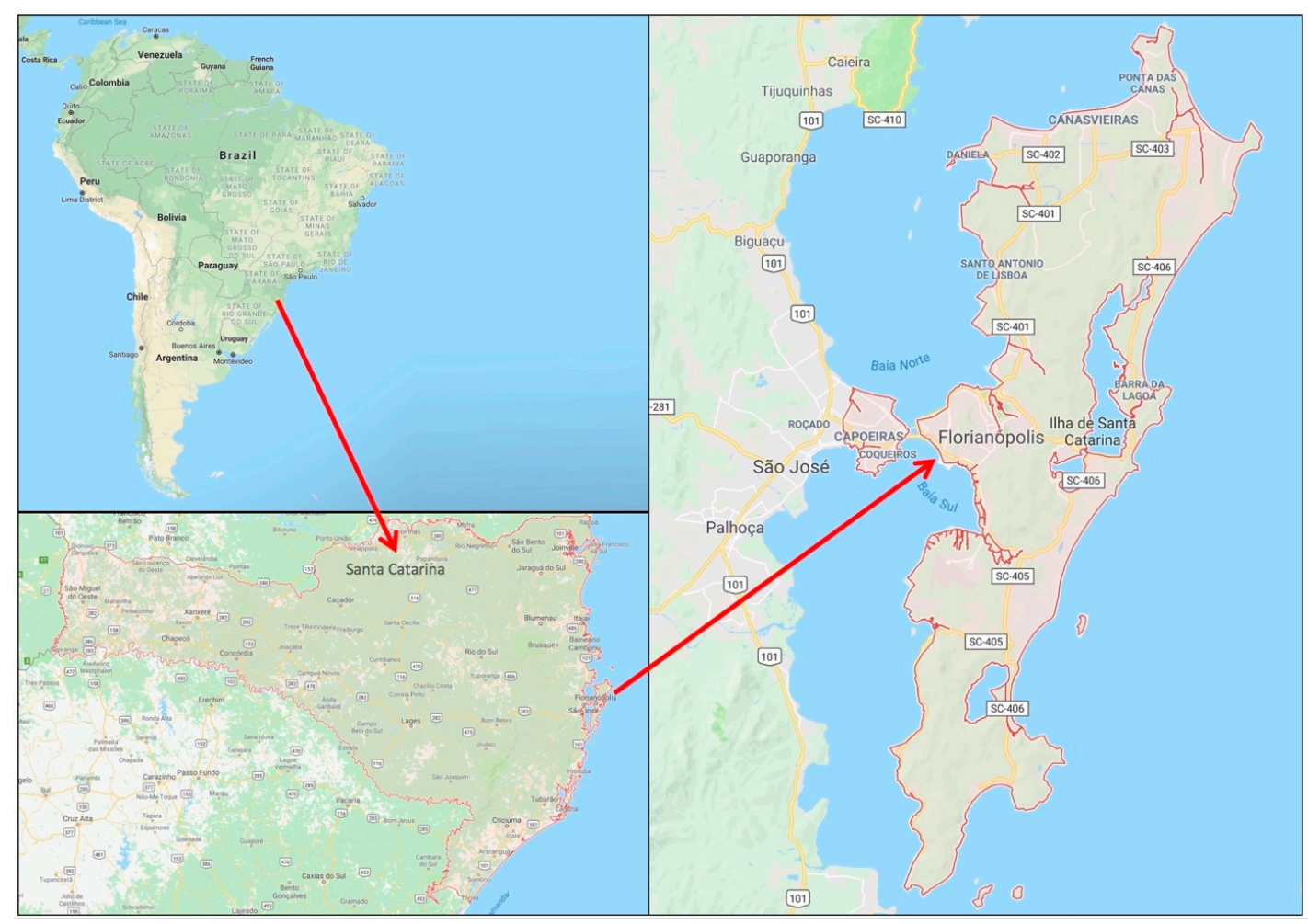

Figure 1. Location of Florianópolis, drawn by authors on a Google Map base map [36]. 
The traditional inhabitants of the city were mainly from an indigenous community-the Carijos. Following the European arrival in the 16th century, a large proportion of the indigenous population died, and those who remained alive were held as slaves, and removed from the city. In 1738, Florianópolis started its urban development journey from the creation of the Captaincy of the Island of Santa Catarina (the main island where Florianópolis is located) due to its geostrategic military significance. This development was sped up by the Portuguese settlers exploiting opportunities for agriculture, manufacturing, and fishing. In 1823, Florianópolis, then named Desterro, became the capital city of Santa Catarina. In 1894, the capital city had its named changed to Florianópolis-in honor of the then president of Brazil, Floriano Peixoto. During the 20th century, Florianópolis initiated the process of modernization that contributed to the further development of the city, stimulating tourism, trade, innovation, and services [35].

During the last several decades, Florianópolis has become a popular international tourist destination, largely for South Americans. Besides its astonishing weather, beaches, and cuisine, Florianópolis also uses its colorful folklore to attract visitors. In 1985, the official city brand of 'Magic Island' was created, inspired by the old mythical tales [37]. The success of the tourism and service sectors generated a potential for the city to diversify its economic activities by moving towards a knowledge and innovation economy. A new city brand of 'Innovation Capital of Brazil' was coined in 2009. Today, Florianópolis is recognized as one of the premier innovation hubs of Brazil [38]. The most recent achievements of the city, at the national stage, have motivated urban administrators to think about turning Florianópolis into a globally recognized smart innovation island. Considering its current achievements and ambitions, a new brand is also suggested for the city of Florianópolis by the authors-that is 'Smart Florianópolis' or in short, 'Smart Floripa'. The salient characteristics of the city are presented in Appendix A; Table A1.

\subsection{Data Collection}

This case report employs two methodological approaches in its investigation, on the city of Florianópolis, to collect relevant data to analyze. These are: (a) reviewing the relevant literature systematically, and; (b) interviewing the key local actors thoroughly.

\subsubsection{Literature Review}

The study adopted a three-stage procedure as the methodologic approach of the systematic literature review. Highlighted by Bask and Rajahonka [39]: (Stage 1) planning stage contains objectives and review protocol for the review, defining sources and procedures for literature searches; (Stage 2) conducting the review stage consists of descriptive analysis; (Stage 3) reporting and dissemination stage includes analysis and synthesis of the results according to the established objectives.

In Stage 1 (planning stage), a research plan involving the research aim and question, keywords, and a set of inclusion and exclusion criteria was developed. The research aim was framed to identify the performance of Florianópolis under the four knowledge-based urban development domains-i.e., economy, society, environment, governance [40]. This helped to set the context for addressing the research question of: What does it take to transform a tourist island into an innovation capital? Therefore, 'Florianópolis', 'economic development', 'societal development', 'spatial development' and 'institutional development' were selected as the main search keywords (their Portuguese translations are also used). The query string used for database searches in English was: (("Florianópolis") AND ("economy" OR "economic development") OR ("society" OR "societal development") OR ("environment" OR "spatial development") OR ("governance" OR “institutional development")). The Portuguese version was: (("Florianópolis") E ("economia" OU "desenvolvimento econômico") OU ("sociedade" OU "desenvolvimento social") OU ("ambiente" OU "desenvolvimento espacial") OU ("governança" OU "desenvolvimento institucional")).

Given the limited literature coverage on the developmental issues of Florianópolis, both academic and grey literatures were targeted. Firstly, for the selection of the academic literature pieces, the Google 
Scholar database was used. The following inclusion criteria were determined with the goal of the selection to relate to and help addressing the research aim and question. All publication types-i.e., journal articles, Procedia papers, books, book chapters, conference proceedings-in English and Portuguese were searched with the abovementioned keywords, but only the full-text and available online literature was considered. The exclusion criteria were determined as publications other than those mentioned in the inclusion criteria. Secondly, all Brazilian universities' websites were manually searched for relevant bachelor, master, and doctoral theses written in English or Portuguese. The same keywords were used in the search. In terms of the inclusion criteria, only the full-text theses, available online, and taking Florianópolis as a case study were considered. The exclusion criteria were kept the same. Thirdly, the grey literature consisting of government, private, and not-for-profit organizations' reports and websites were searched through the Google search engine by using the same keywords. In terms of the inclusion criteria, only full-text publications and websites in English and Portuguese were considered. The exclusion criteria were kept the same.

In Stage 2 (conducting the review stage), the search task of the relevant literature pieces was undertaken in April 2018. No starting publication date was introduced in the search, where the end date was when the search was conducted in April 2018. The keywords were directed to the titles and abstracts of the searched academic literature pieces. The abstracts of the selected articles were read. In the case that abstracts were found relevant, full-texts were read to decide whether to include the article in the review pool, considering the inclusion and exclusion criteria. As for the grey literature, the keywords were directed to the full-texts, and were read to decide whether to include the article in the review pool, considering the inclusion and exclusion criteria. Initially, the search returned in total 69 academic and grey literature pieces. All of them were 'eye-balled' for consistency and accuracy of the keyword search [41]. After evaluating the abstracts (or full-texts of the grey literature were skim read) against the research aim and also removing duplicates, this figure was brought down to 47 literature pieces. The full-texts of these initially screened literatures were then read carefully against the research aim. This resulted in the selection of the final 36 pieces, as shown in Appendix C, Table A2. Lastly, these pieces of literature were re-read, reviewed, and analyzed.

In Stage 3 (reporting and dissemination stage), the work focused on writing up and presenting the findings. At the write-up stage, other publications on the topic were also incorporated as additional supporting literature evidence to better analyze the topic and elaborate the overall findings. The findings of the review were used to support and elaborate the profiling of the development and transformation process of Florianópolis.

\subsubsection{Interviews in Focus Group Meetings}

Following the systematic review of the literature, the study adopted a semi-structured, interview-based approach to carry out the empirical investigations on the selected case study. The purpose here was to capture the perceptions of key actors on the opportunities and challenges the city faces, and the likely solutions to those issues. The interview exercise was designed to discuss various developmental issues with the key local actors of Florianópolis. The goal of these interviews was to capture the perspectives of these actors, that have a say in the city's policies and future development, on critical matters. In order to gain a holistic understanding, the perceptions of a range of key local actors were taken into consideration from public institutions, non-governmental agencies, and academia. Interviews took place in Florianópolis between May and August 2018 with 14 key local actors. These actors were high-ranked policymakers, and senior professional practitioners representing local (city and state) and national organizations, along with local and regional senior academics with expertise on the relevant areas. The interviewed actors were from the following organizations: State Government of Santa Catarina, Local Government of Florianópolis, Federation of Trade in Goods, Services and Tourism Santa Catarina, National Service of Commercial Learning Santa Catarina, Brazilian Association of Software Companies, Brazilian Institute of Zero Waste, Federal University of Santa Catarina, and University of Caxias do Sul, as shown in Table 1. 
Table 1. Profiles of the interview participants.

\begin{tabular}{ccc}
\hline No & Institution & Position \\
\hline 1 & State Government of Santa Catarina & Senior State Development Officer \\
2 & State Government of Santa Catarina & Economic Development Officer \\
3 & Local Government of Florianópolis & Senior Architect \& Urban Planner \\
4 & Local Government of Florianópolis & Senior Innovation Policy Officer \\
5 & Federation of Trade in Goods, Services \& Tourism Santa Catarina & Senior Economist \& Social Scientist \\
6 & Federation of Trade in Goods, Services \& Tourism Santa Catarina & Senior Business Performance Analyst \\
7 & National Service of Commercial Learning Santa Catarina & Tourism and Education Specialist \\
8 & National Service of Commercial Learning Santa Catarina & Science and Technology Specialist \\
9 & Brazilian Association of Software Companies & Director and Business Analyst \\
10 & Brazilian Institute of Zero Waste & President and Environmental Scientist \\
11 & Federal University of Santa Catarina & Professor of Urban \& Regional Studies \\
12 & Federal University of Santa Catarina & Professor of Innovation Studies \\
13 & Federal University of Santa Catarina & Professor of Knowledge-Based Development \\
14 & University of Caxias do Sul & Professor of Information Science \\
\hline
\end{tabular}

The interviews were planned in the form of a set of focus group meetings. In total, four meetings were held in each month between May and August 2018. Each of these meetings lasted between three and four hours in an interactive workshop format. Most of the interviewees (or focus group members) were present in all of the four meetings. However, where an interviewee could not physically attend a workshop, alternative options were offered to capture their opinions, such as joining the workshop virtually or visiting them in their offices at a later day.

The study adopted the following procedures used in the research work of Pancholi et al. [42,43]: Firstly, as highlighted by Yin [44], in order to make a single case study method successful, it is necessary to utilize multiple sources of evidence as data. Hence, the data from the interviews were integrated with others collected from primary and secondary sources-i.e., literature review findings, and policy and plan documentation obtained from government organizations and other institutes. Secondly, other sources, such as field observations, photographs, physical plans, and maps, also contributed to the analysis as primary data sources in three ways [45]: (a) prior to interviews, to identify issues to form specific questions; (b) during interviews (or focus group meetings or workshops), to support the discussion, such as maps and other spatial data; (c) post-interviews, to confirm the findings. Thirdly, in order to carry out the analysis, a multidimensional conceptual framework for knowledge-based urban development, as shown in Figure 2, was adopted to integrate the diverse developmental perspectives together [46]. Fourthly, a content analysis, informed by phenomenographic methodology [47], is used to analyze findings and derive the attributes from the participants' perceptions. Lastly, the analysis is done through manual coding to identify the themes emerging in the form of significant concepts overarched by the guiding framework. Data from the different groups of interviewees contributed to different dimensions of the framework.

The workshops were chaired and moderated by a master of ceremony, and two project administrators were present to capture the key messages by manually recording them (taking notes in turns) and collecting the written material produced during the workshops. These notes were then transcribed into a document and converted into workshop meeting notes. After each meeting, these notes were circulated to the participants for confirmation of the minutes and the detailed discussions and highlights of the meetings. After the fourth workshop, all meeting notes were combined and forwarded to the participants. Participants were asked to put their consolidated views into a memo-style written piece representing their institutions and own perspectives on the knowledge-based urban development progress and challenges of the city. The meeting notes and memos were used for the analysis of local actors' perceptions on the development achievements, potentials, opportunities, and challenges of Florianópolis. By adopting this procedure, we meet the criterion of theoretical saturation, establishing the empirical validity of the data obtained [48]. 


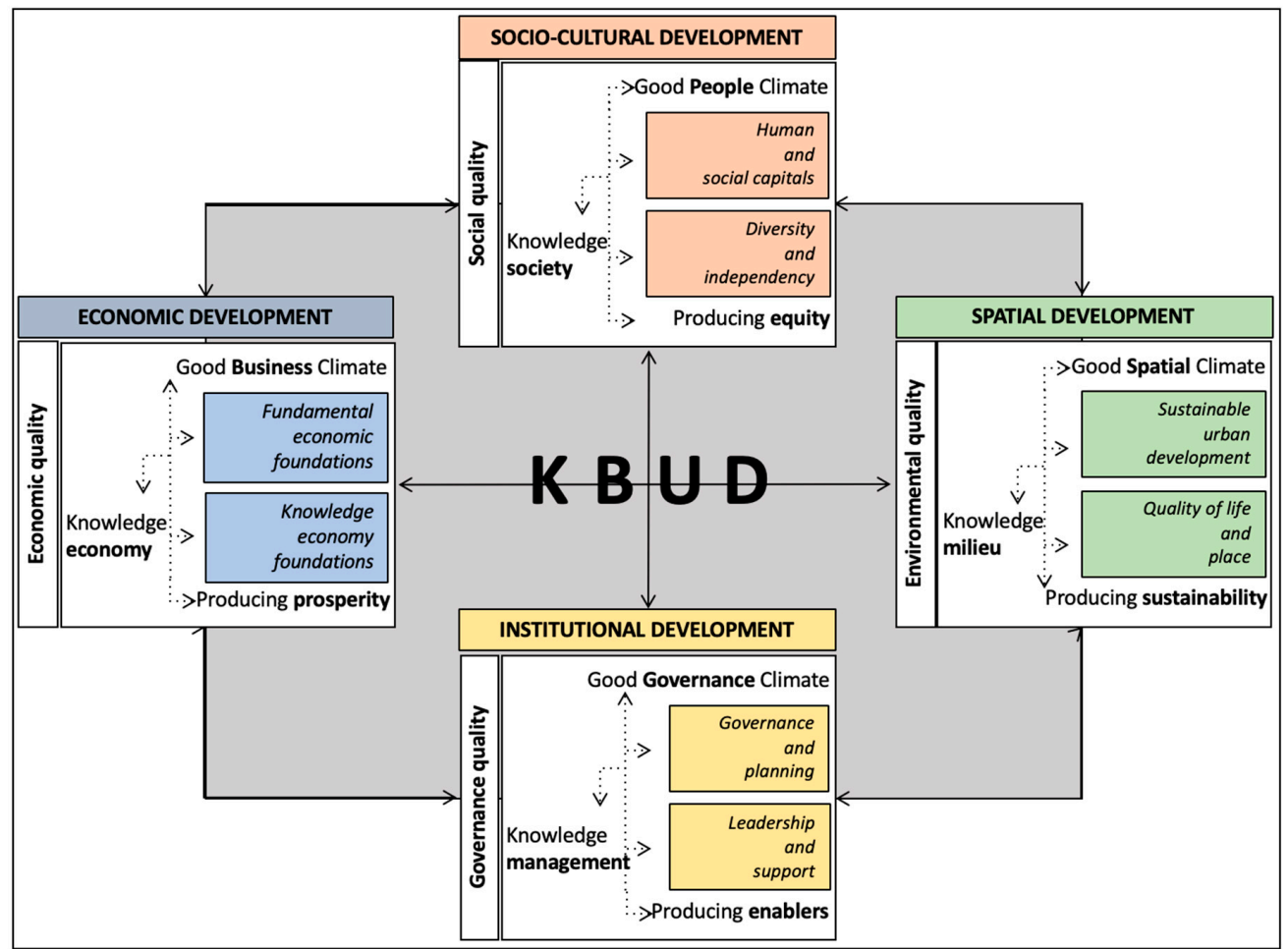

Figure 2. Conceptual framework of knowledge-based urban development (KBUD), derived from Reference [46].

The first workshop, that was held in May 2018, was used to introduce the project team and participants, and present the aims and objectives of the study. Conceptual and practical issues were also presented to the group and their roles and expectations were discussed. This helped us to determine some key priorities that local actors wanted the project to specifically focus on. The second and third workshops, that were held in June and July 2018, adopted the following format. In each workshop the project team, in the first hour, provided background to the study and summarized the highlights from the previous meeting. This was followed by, in the second hour, presenting a set of issues and questions to start the conversation between the participant key local actors. However, discussions were not limited to these issues, and in some instances, this led to inspiring debates on the topic and seldomly on its tangents. Table 2 lists the five-what and five-how questions directed to the participants. In the last hour, discussed issues were recapped and a consensus was sought in the case of disagreement. Additionally, participants were asked to put together their personal and institutional perspectives in a brief report (or memo) until the final meeting. The last workshop was held in August 2018. This workshop particularly focused on the presentation and discussion of the participant prepared memos and on establishing a consensus on, or recording the conflicting views on, various developmental related issues concerning Florianópolis.

Table 2. Five-what and five-how discussion starter questions.

\begin{tabular}{cc}
\hline No & Question \\
\hline 1 & What are the key economic development strengths and weaknesses of Florianópolis? \\
2 & What are the key societal development strengths and weaknesses of Florianópolis? \\
3 & What are the key spatial development strengths and weaknesses of Florianópolis? \\
4 & What are the key institutional development strengths and weaknesses of Florianópolis? \\
5 & What are the key milestones of Florianópolis' knowledge-based urban development and smart city journey? \\
6 & How has the transformation of Florianópolis from a tourist island to smart innovation island been formulized? \\
7 & How effective are the policy mechanisms in Florianópolis to achieve a thriving knowledge-based urban development? \\
8 & How can encountered challenges of Florianópolis in the knowledge-based urban development journey be tackled? \\
9 & How can the progress of Florianópolis be sustained given the downturn of the national economics and politics? \\
10 & How can Florianópolis become an internationally recognized location for smart and sustainable development? \\
\hline
\end{tabular}




\section{Results}

The findings of the study are reported in this section under the four categories based on the conceptual framework of knowledge-based urban development presented in Figure 2. These are economic, societal, spatial, and institutional development domains. Additionally, a sub-section on knowledge-based urban development challenges and opportunities is also included. The narrative of the findings is specially designed to disclose the developmental journey of the city as much possible in a chronological order. Moreover, a timeline of Florianopolis' developmental milestones is also developed, as shown in Appendix B, Figure A1. The reason for this approach was to form a comprehensive document to tell the story of Florianópolis and its new path creation efforts in detail. In turn, this may help inform the policy circles of the city and beyond.

\subsection{Economic Development}

The main economic activities in Florianópolis cluster around the commercial and service sectors-representing over $95 \%$. Retail, public, hospitality-tourism, and technology-innovation sectors have almost a similar share in this figure-each representing about $20-30 \%$. There also exists marginal levels of agricultural and maricultural (less than 1\%) and limited light manufacturing (over 3\%) activities in the city [34].

\subsubsection{Tourism and Gastronomy}

Despite the tourism potential of Florianópolis that was identified in the 1920s, the lack of infrastructure became an impediment [49]. Only in the 1970s, after the development of urban infrastructure and availability of public incentives and private investment, tourist lodging, sustenance, and entertainment projects were initiated [50]. From then onwards, tourism began to influence the growth directions of the city, advancing the development towards the beaches of the northern part of the island, as shown in Figure 3, and the main lagoon area-i.e., Lagoa da Conceição-through the highways [51].

Florianópolis Urban Development Plan in 1981 and Balneários Master Plan in 1985 were prepared with an aim of transforming Florianópolis into a tourist island [52]. In this period, publicity campaigns were intensified and the city was promoted as the South American Tourist Capital along with the official city brand of 'Magic Island'. The inauguration of the International Airport in 1976 and its expansion in 1988, allowed a greater flow of tourists into the city [53]. From the 1990s, seeking to circumvent the seasonality of tourism, Florianópolis extended its activities to strengthen business and event tourism-such as the opening of the Centro Sul Convention Centre. Today, the convention center is one of the most popular events centers in Brazil [54]. Some hotels in the city made alterations to meet the increased demand and (inter)national hotel chains began their operations from 1995 onwards [55]. According to the Brazilian Hotel Industry Association of Santa Catarina (ABIHSC), the city has 535 hotels with over 38,500 bed capacity. Along with the summer housing stock, Airbnb type accommodation options, and people self-renting out their homes while on vacation, the tourist bed capacity of Florianópolis reaches to well over 300,000 beds.

In addition to the sun-and-sea, business, and events tourism, other tourism segments were also strategically targeted-i.e., eco, party, sports, LGBT, high-end, gastronomic. Besides the Florianopolis Carnival, various annual off-peak tourism season events, such as the Ironman Triathlon (since 1998), Oysters Festival (since 1999), LGBT Parade (since 2005), and an out-of-season carnival (since 2006), are being held in the city [49].

Achievements in the gastronomic tourism area resulted in Florianópolis receiving the 'UNESCO Creative City of Gastronomy' recognition in 2014. Since then, actions have been taken to professionalize the gastronomy sector by improving the quality of dishes and services, encouraging the consumption of ingredients from local and regional producers, respecting the seasonality of the ingredients, and developing a Florianopolitan gastronomic identity—mainly based on authentic seafood dishes. 
To further support the gastronomy sector, the production of seed oysters commenced in 1994 with the support of the Federal University of Santa Catarina (UFSC) [56].

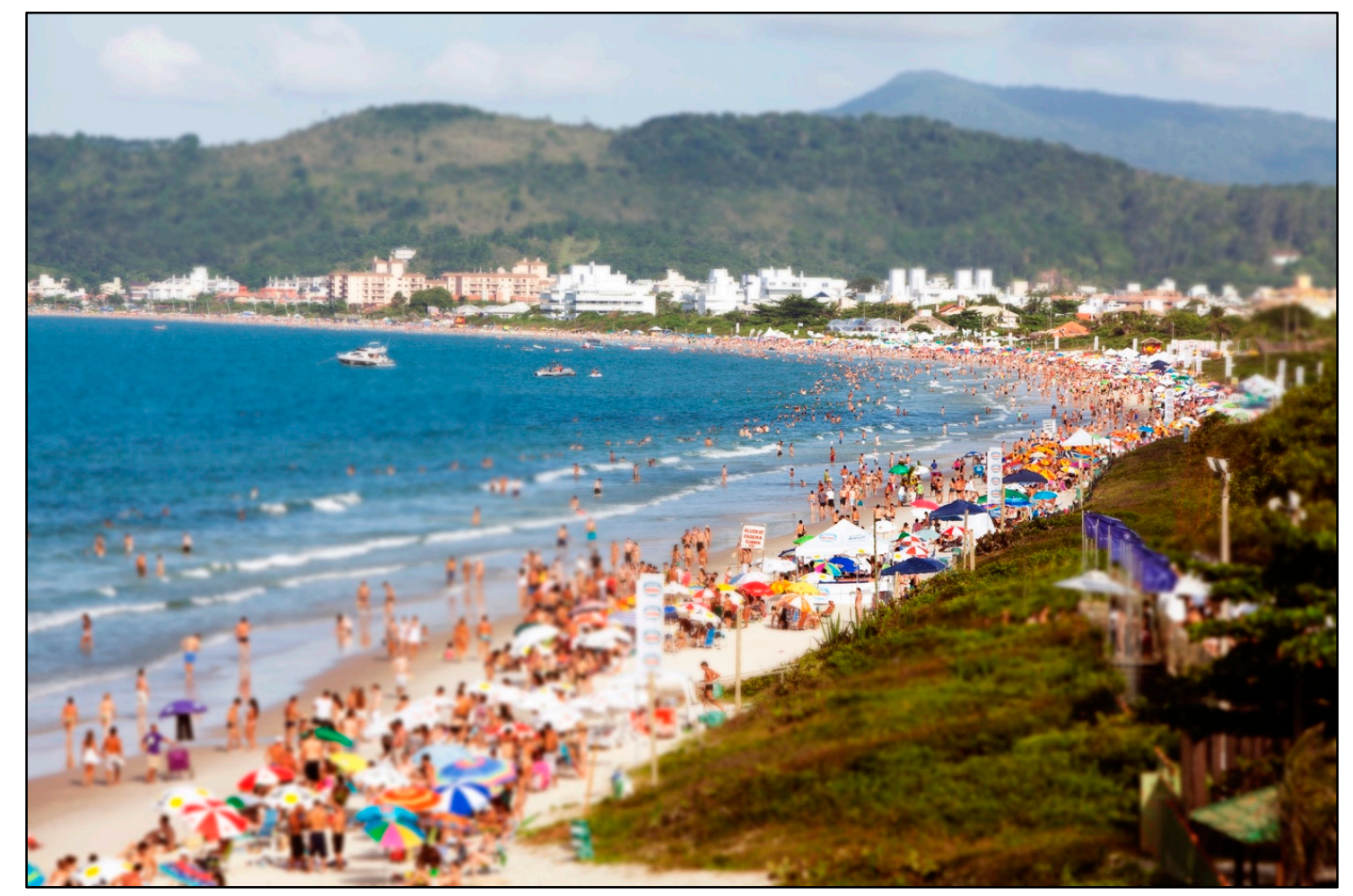

Figure 3. A view of the Jurere International Beach, reproduced with permission from Eduardo Zappia (photo taken in February 2018).

\subsubsection{Technology and Innovation}

During recent years, Florianópolis has been making significant progress in knowledge-based economic activities. One of the primary reasons for that is its higher education system fostering human capital. The first higher education institution in the city was established in 1909, Federal Institute of Santa Catarina (IFSC). The subsequent institutions established were UFSC in 1960, University of South Santa Catarina (UNISUL) in 1964, and State University of Santa Catarina (UDESC) in 1965 [57].

At the federal-level, endeavors aiming to cultivate the Brazilian science and technology sector focused on the establishment of a number of key institutions. These include: National Council for Scientific and Technological Development (CNPq) in 1951; National Bank for Economic and Social Development (BNDES) in 1952; Southern Regional Development Bank (BRDE) in 1961; Brazilian Innovation Agency (FINEP) in 1967; and National Fund for Scientific and Technological Development (FNDCT) in 1971 [58]. The creation of Telebrás Research and Development Centre (CPqD) in 1974 boosted the telecommunication sector in the country. Florianópolis responded with the emergence of high-tech companies-e.g., Intelbrás in 1976, Dígitro in 1977, Eletrosul in 1978. These companies employed graduates of local universities and attracted specialized professionals to Florianópolis from other Brazilian cities [59].

At the state-level, during the last several decades, the technology sector has been targeted as the key driving force behind innovation. The establishment of the State Development Agency of Santa Catarina (BADESC) in 1975 generated the most needed support opportunities for the development of technology companies and initiated the innovation ecosystem formation in the state. In 1972, Santa Catarina Branch of Brazilian Institute of Management Assistance to Small and Medium Enterprises (IBAGESC) was created to promote training courses, facilitate access to financial services, stimulate cooperation between companies, and organize commerce fairs and business roundtables. 
In 1991, IBAGESC was renamed as Santa Catarina Branch of Brazilian Micro and Small Business Support Service (SEBRAESC) [59].

At the local-level, the local government was concerned by the evident economic growth limitations of the city as an island. For example, as Florianópolis is an ecologically sensitive island, industrial developments are not permitted in its territory. In 1985, a municipal law (\#2193/1985) was passed for the city to reinvent itself through knowledge economy drivers-basically to foster, attract, and retain talent and investment [60].

In the mid-1980s, the technology sector was established to generate high-value-added product and services in Florianópolis. In this direction, the first research and development (R\&D) organization, Centers of Reference in Innovative Technology Foundation (CERTI), was created in 1984. This is followed by the Association of Technology Companies in Santa Catarina (ACATE) in 1986, gathering entrepreneurs to foster a technology and innovation ecosystem, and arousing the development of public policies in the state and the city. In the same period, the first incubator of Florianópolis, the Business Centre for Advanced Technologies Technology (CELTA), was created by CERTI.

At the federal-level, the mid-1980s marked the knowledge economy noteworthiness by the foundation of the Ministry of Science and Technology (MCTIC) in 1985 and the creation of the National Associations of Entities Promoting Innovative Enterprises (ANPROTEC) in 1987. ANPROTEC annually awards the best incubators and technology parks in the country. Thus far, Florianópolis is the only Brazilian city with two award-winning incubators (i.e., CELTA, MIDITEC). These incubators showcase the best practice incubation models in Brazil [38].

The efforts in creation of institutions to provide support for the development of an innovation ecosystem in Florianópolis was notable in the 1990s. Santa Catarina Research and Innovation Support Foundation (FAPESC), established in 1990, has made the collaboration between academia and companies possible and feasible. During this period, a number of successful software companies were created-e.g., Softplan in 1990, Reason/ Alstom in 1991, Nexxera Group in 1992, Dot Group in 1996. In 1993, with the support of the state, ParqTec Alfa was created to accommodate growing numbers of technology-based enterprises that were surfacing from incubators and condominiums-equivalent to garage start-ups [61].

In 1994, the National Service for Industrial Training (SENAI), a network of not-for-profit secondary level professional schools, established and maintained by the Brazilian Confederation of Industry (CNI), inaugurated the Centre for Technology in Automation and Information Technology (CTAI). CTAI offers the industries of Santa Catarina a technological center capable of developing and transferring technology, with actions focused on quality and continuous improvement aiming at industrial competitiveness. In 1996, GERASUL, a state-owned energy company based in Florianópolis, was acquired by Belgian Tractebel. In 2015, its name changed to ENGIE-the only top-100 Brazilian company located in Florianópolis.

The Municipal Law (\#4913/1996) offers tax exemption over services and land allocation for the companies established in the Industrial Computer Condominium and ParqTec Alfa. The growth of the technology sector pledged the development of another incubator in Florianópolis, MIDI Tecnológico, in 1998. It is managed by ACATE and maintained by SEBRAESC. The Network of Entities Promoting Technology Enterprises in Santa Catarina (RECEPETI) was founded in 2001 to improve the integration of incubators throughout the state. In 2013, its name was changed to the Catarinense Innovation Network.

In the late-2000s, Florianópolis started to be recognized both nationally and internationally. In the mid-2000s, the federal government took an important step towards promoting innovation and scientific and technological R\&D by passing the Innovation Law (\#10973/2004) that brings together companies and universities. The Good Law (\#11196/2005) grants tax incentives to companies that carry out R\&D of technological innovation [62]. Benefiting from these laws, in 2006, Sapiens Parque was conceived as an innovation park in Florianópolis. In 2013, it was included in the network of 13 innovation centers across the state. 
Brazilian magazine Você S/A highlighted the city as one of the best Brazilian cities in which to work. Another national magazine, Exame, mentioned the city as one of the best cities to do business in Brazil. The Getúlio Vargas Foundation highlighted the city as the country's first capital in digital inclusion. Newsweek considered Florianópolis one of the top-ten most dynamic cities in the world. Florianópolis received mentions from BBC and Italian Corriere della Sera as the likely 'Silicon Valley of South America'.

In 2008, a program to promote innovative entrepreneurship-the Innovation Synapse Program-was conceived to offer financial resources, capabilities, and support to transform innovative ideas from different sectors of the knowledge economy into successful ventures for boosting the innovation ecosystem. In 2009, a new city brand, 'Innovation Capital of Brazil', was coined for Florianópolis by ACATE [63]. The joint effort constituted the positioning of the city, highlighting its innovative initiatives promoted not only by technology companies, but also universities, service companies, and the maricultural sector.

An 'Innovation Route' in Florianópolis was planned in 2013. The route aims to connect companies, academia, government, and community to leverage entrepreneurial and innovative potential in the city. An electric bus (locally developed technology) operates on the route-circulating between UFSC and the Sapiens Parque [64]. In 2017, two major companies were located on the innovation route-Peixe Urbano, one of the largest e-commerce companies in Latin America, and EMBRAER, the third largest aircraft manufacturer in the world. Figure 4 illustrates the location of high-tech company clusters on the innovation route.

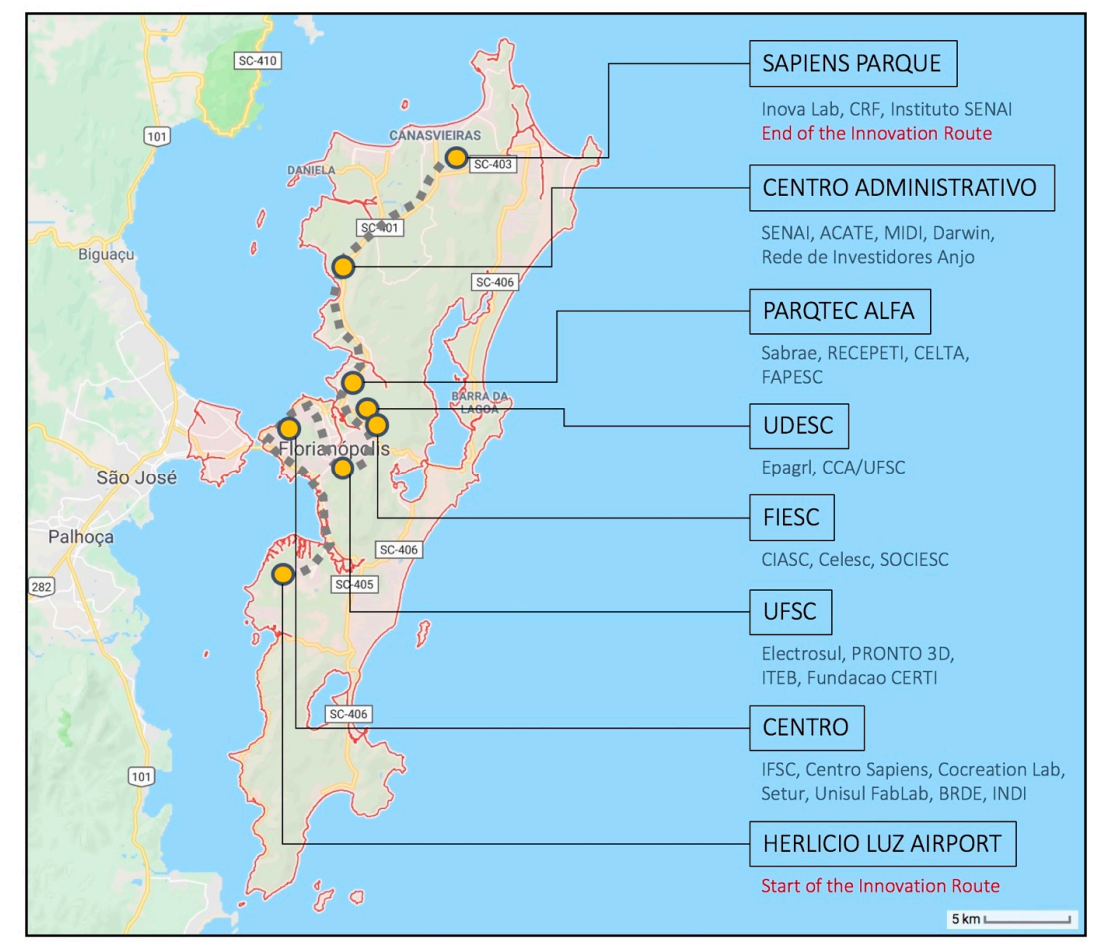

Figure 4. Location of the innovation route, drawn by authors on a Google Map base map [65]. SENAI: National Service for Industrial Training; ACATE: Association of Technology Companies in Santa Catarina; RECEPETI: Network of Entities Promoting Technology Enterprises in Santa Catarina; CELTA: Business Centre for Advanced Technologies Technology; FAPESC: Santa Catarina Research and Innovation Support Foundation; UDESC: State University of Santa Catarina; UFSC: Federal University of Santa Catarina; IFSC: Federal Institute of Santa Catarina; BRDE: Southern Regional Development Bank; CRF: Regional Council of Pharmacy; CCA: Center for Agrarian Sciences; FIESC: Federation of Industries of Santa Catarina; CIASC: Center of Informatics and Automation of the State of Santa Catarina; SOCIESC: Educational Society of Santa Catarina; ITEB: Rubber Technology Industry; INDI: Integrated Institute of Economic Development: CENTRO: City Centre. 
Knowledge-based economic development endeavors of Florianópolis-through the evolution of human capital via its educational institutions and attractiveness, creativity in new product and service development, incentives, and legislative promotions-helped its gross domestic product (GDP) to be one of the highest among the Brazilian capital cities. The technology sector of Florianópolis makes more than $\mathrm{R} \$ 4.3$ billion per annum (about US $\$ 1$ billion) and employs over 17,000 people. Florianópolis is ranked nationally: second most entrepreneurial city; second for access to venture capital; third for access to capital; third for innovation [66].

\subsection{Societal Development}

In order to support the growth of the innovation economy, numerous institutes contributed to the development of human capital on two fronts: training human resources and fostering entrepreneurs [67]. In terms of tertiary education, aforementioned institutes train prospective knowledge workers. According to the 2017 Census of Higher Education, over 45,000 students were enrolled in universities, where more than half of these resided in Florianópolis. In terms of skill development, National Service of Commercial Learning's (SENAC) Florianópolis branch delivers short-term technical qualification courses. In terms of fostering entrepreneurs, the Foundation for Research and Innovation Support of the State of Santa Catarina (FAPESC) supports research and innovation, education infrastructure development, scientific dissemination, and training [68]. Along with this, the 2018 federal regulation, introducing a Legal Framework for Science, Technology and Innovation, encourages collaboration between research centers, companies and public agencies.

Whilst the development of human capital in Florianópolis is promising, the same is not true for social capital and community development and cohesion. Florianópolis is a city of segregated settlements. This is due to the geographical and social conditions that generate a socially incohesive city form. In other words, socio-spatial segregation in the city is evident-the dominant social class in each neighborhood is clearly visible. Waterfront areas are generally occupied by higher-income groups and the environmentally fragile areas, such as hills and mangroves, by lower-income groups. Moreover, wealthier people reside in planned areas, where lower-income groups mostly in informal settlements, so-called 'favelas' - precarious human settlements originally resulting from the invasion of both private and public urban areas [69].

Over $80 \%$ of favelas are situated in the central city area-mostly in the hilly parts. In general, favelas neither have access to the main public services such as water, sewerage, electricity, street lighting, and garbage collection, nor to the facilities such as squares, schools, nurseries, and health centers. However, in the case of Florianópolis, most of these services are provided to the favelas. While the human development index score of the city is 0.847 , the score goes down to 0.390 for the favela areas of the city [70]. There are only a few places that allow greater social interaction-such as parks and other public spaces. Beaches are the most democratic spaces of the city and the carnival time is the most inclusive time of the year, as shown in Figure 5.

According to the Ministry of Social Development, $10.16 \%$ of the households have income of up to half a minimum wage and $3.7 \%$ of the households receive government payments to move out of the extreme poverty level. According to the Atlas of Human Development in Brazil in 2013, the ratio of low-income groups in Florianópolis comes to a decline-9.63\% in 1991, then $5.31 \%$ in 2000, and $1.35 \%$ in 2010. The ratio of the richest $20 \%$ to the poorest $20 \%$ fell from $21.92 \%$ in 1991 to $16.96 \%$ in 2010 [71]. However, these figures might be worsening in the near future as the economy took a downturn in recent years.

In line with a declining national economy since 2013, the unemployment rate in Florianópolis jumped from $3.8 \%$ in 2012 to $7.5 \%$ in 2017-still being well below the national average of $13.1 \%$. In 2016, the average monthly salary was 4.7 minimum wages (15th in Brazil) and the proportion of employed persons in relation to the total population was $66.3 \%$ (17th in Brazil)-minimum monthly wage is around $\mathrm{R} \$ 1000$ or about US\$240 [72]. However, given that in many national rankings the city places in 
the top five-technology company concentration, quality of life, human development index-in terms of these socioeconomic figures, the city is placed well behind many other national locations.

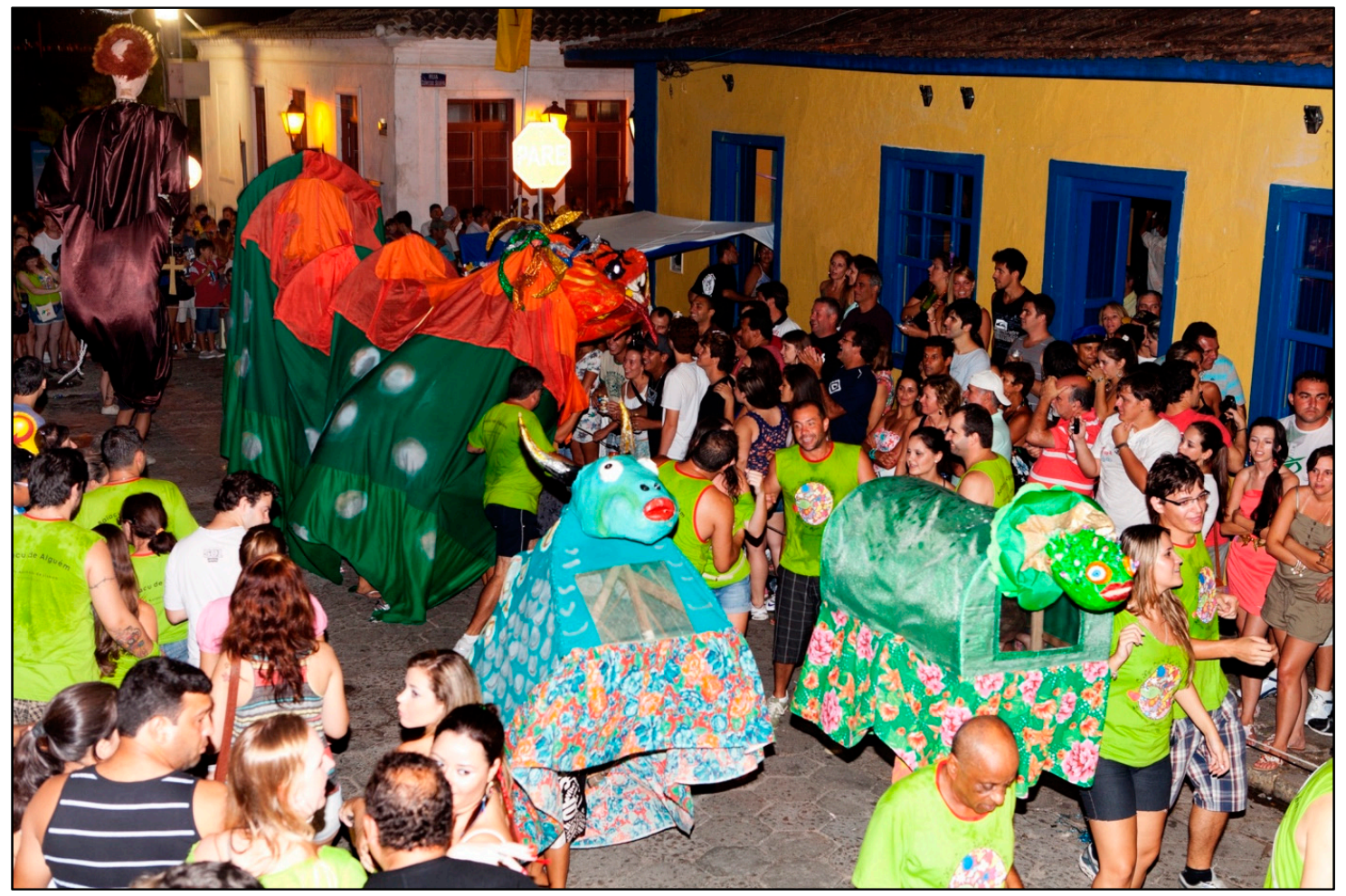

Figure 5. A view of the Florianópolis Carnival, reproduced with permission from Eduardo Zappia (photo taken in February 2018).

Community development and integration is supported with several public policies. Federal policies have been more effective in providing relative equality in education, health, and shelter areas. A social protection network was established in Florianópolis jointly by public and private entities to implement social assistance and community integration policies. The most active member of the network is Padre Vilson-a church-based organization. The public entities include all three tier governments and the most active private entities are Social Good Brazil and Greater Florianópolis Community Institute (ICOM). Public institutions house a number of reference centers for social assistance located in close proximity to the neediest communities [73].

\subsection{Spatial Development}

\subsubsection{Built Environment and Infrastructure}

The first master plan of Florianópolis was approved in 1955. This was followed by the second master plan in 1977. Following the downtown area's densification as shown in Figure 6, according to these plans, the urban expansion continued towards an area called Bacia do Itacorubi-particularly after the establishment of the UFSC university campus in the 1960s and Eletrosul enterprise (a major Brazilian energy company) in 1978. The municipality launched a master plan, Plano da Trindade, for the area in 1982. The plan, in addition to allocating land for housing for the new residents, also introduced zoning for environmental conservation-fully and partially preserved areas [53].

In 1985, the Balneários Master Plan offered for the first-time conditional development permission for the island's countryside. Although numerous new projects were developed in the northern area- e.g., Canasvieiras, Jurere International-most of the expansion was zoned as rural use and the development was informal. The areas with rural nature were occupied by informal housing —over 
$50.39 \%$ of the urban footprint, as shown in Figure 7. This plan defined the boundaries of the northern and southern preservation areas and only permitted a small neighborhood development at the countryside as a polycentric development zone. The central district master plan was revised in 1997 and the city master plan was approved in 2014. Despite planning regulations and development controls, informal land occupation and development continue to be a major problem in Florianópolis [74].

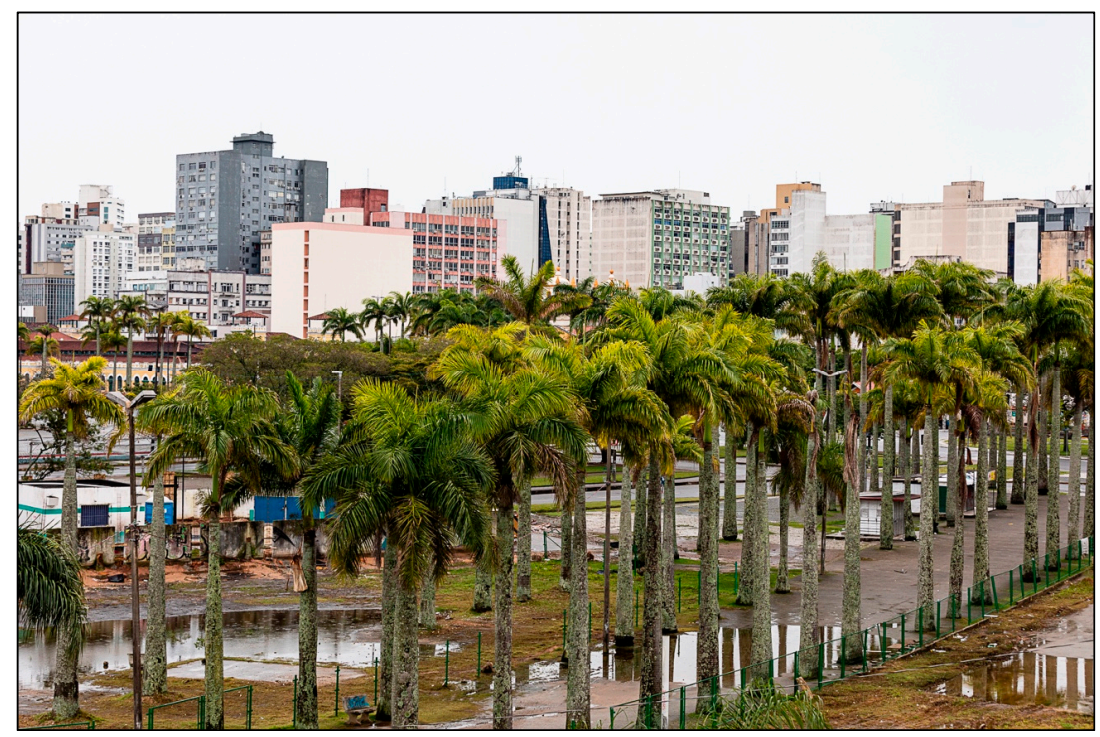

Figure 6. A view of downtown Florianópolis, reproduced with permission from Eduardo Trauer (photo taken in February 2018).

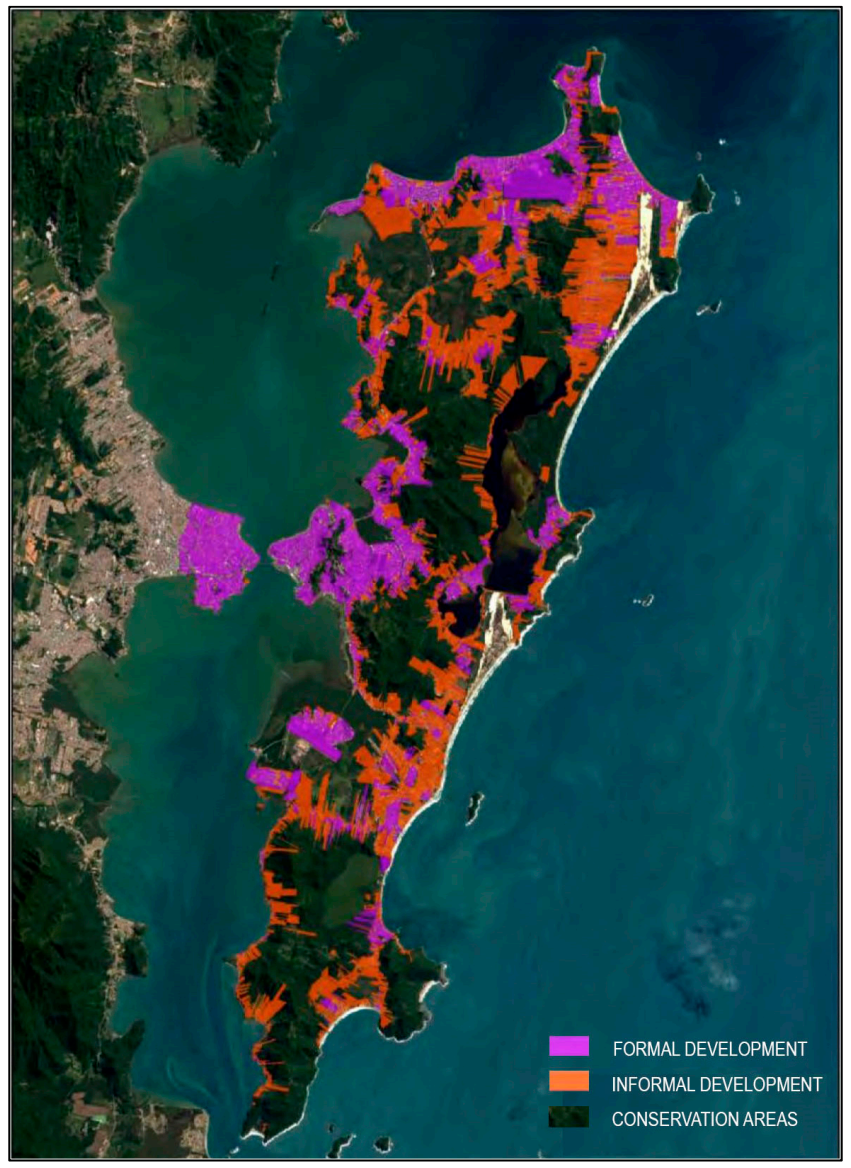

Figure 7. Formal and informal urban development, and conservation areas [73]. 
There is still quite a large part of the island that has not been subjected to exploitation. This is partly because of the existing planning mechanisms that do not allow rural zoned countryside land to be subdivided, because the former land ownership regulation did not permit individuals or corporations to own land on islands. However, the constitutional amendment (\#46/2005) allows land ownership. This legislative change made legalization possible for informally occupied land and development. Furthermore, another recent federal land regularization legislation (\#13465/2017) gave power to island municipalities to produce regularization policies to solve the informal occupation and development issue.

The risk still exists for further land exploitation as there is a general belief that if land is occupied eventually it will gain a legal status. Despite having large informal settlement areas, Florianópolis does not have too many favelas. This is due to most of the informal urban areas in the city, rather than low-income individuals, being occupied by middle-class households. Most of the favelas exist in the hills behind downtown-formed between 1970 and 2004, as shown in Figure 8. According to Oliveira-Musse et al. [75], in 2012 in Florianópolis, 13,231 households were residing in favelas. The surrounding municipalities house a larger number of favelas, where a considerable portion of the island's workforce lives.

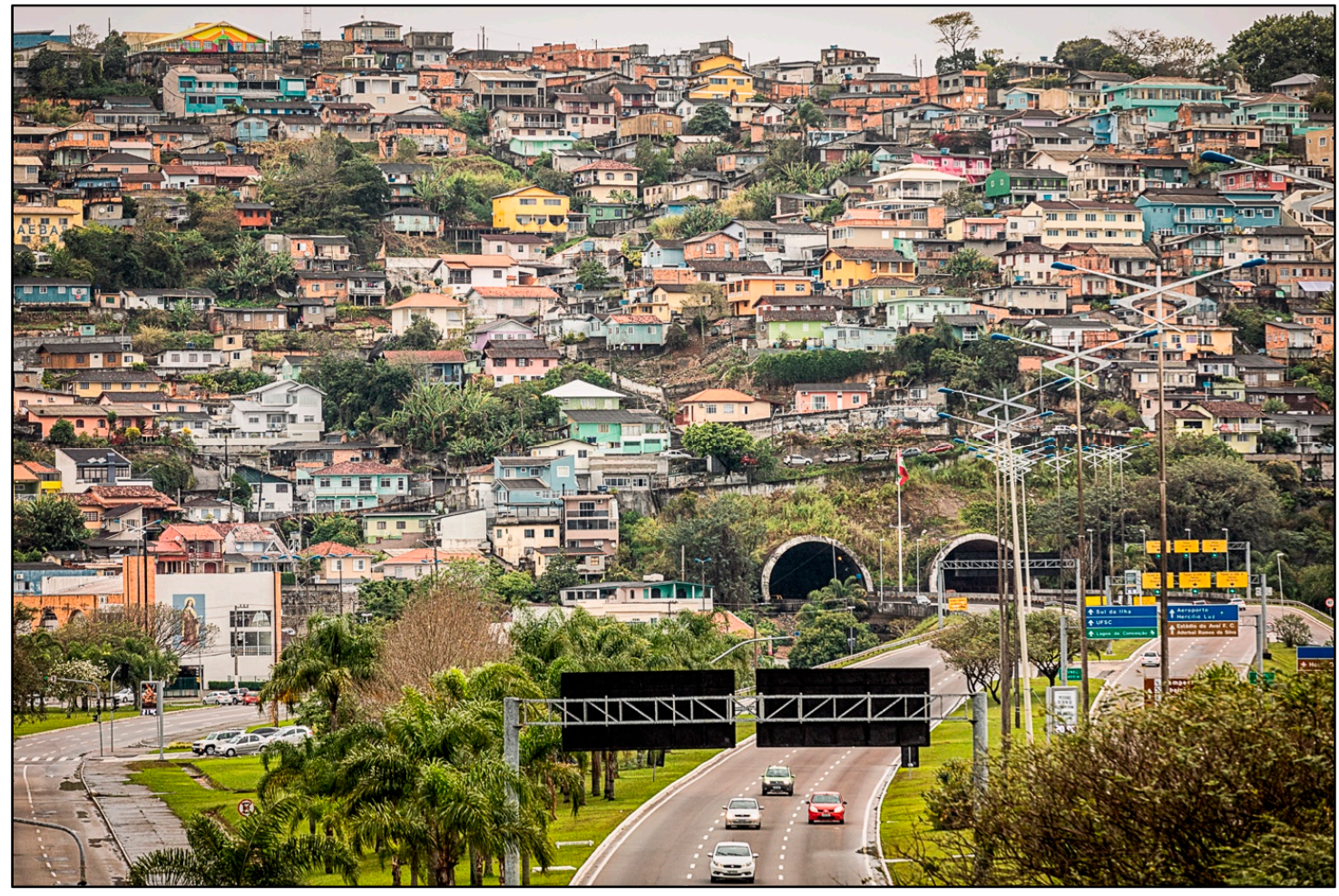

Figure 8. A view of the favelas, reproduced with permission from Eduardo Trauer (photo taken in February 2018).

In order to solve the favela problem, the Social Housing Plan was approved in 2012. The plan provided directions to solve the problem in the city within the 15-year period by building new housing, constructing infrastructure in slum areas, and improving precarious houses [68]. However, federal funds provided to support the plan were not sufficient to carry out the required works. Interestingly, Florianópolis has about $24 \%$ unoccupied housing stock, one of the biggest rates in Brazil-13\% used occasionally as summer house and $11 \%$ kept totally vacant.

Urbanization processes and lifestyle offerings generated rapid population increase and gentrification of the city. Amongst the residents, only less than half of them (47\%) were born in the city. Accessibility and mobility are among the main problems in Florianópolis-particularly during 
the summer months when the island population almost doubles. According to Guerra et al. [35] (p. 216) "Florianópolis provides no concrete policy for promoting sustainable transport practices. This is evident in the robust growth rate of its car fleet, and hence a large increase in traffic levels". Fatal traffic accidents are part of daily life; 351 lives were lost on the highways between 2001 and 2017 [76].

While mobility is determined as one of the major challenges for the city to tackle, there are limited actions taken to better integrate land use and transport with sustainable considerations to the people and the environment of the city [77]. This also relates to the limited focus on sustainable urban development and climate change mitigation aspects in the planning circles of the city. The planning documents that emphasize sustainability issues are rather recent and have not found much implementation opportunity yet [71]. Likewise, despite the gaining popularity of the smart city notion [78] and the smart and resilient urban infrastructure concept [79] being widely pronounced and discussed by both state and local planning authorities; so far, no smart city strategy framework development or planning steps have been taken in the city or the state.

\subsubsection{Natural Environment and Conservation}

Population increase and informal land occupation problems are among the issues risking environmental integrity of Florianópolis. Environmental factors and quality of life attract more people—tourists, knowledge workers, and informal settlers [80] — but as ecosystems are under pressure by human activities, an increase in population leads to major environmental problems-and thus reversing the quality of life. The housing deficit in Florianópolis led to the growth of informal housing settlements to accommodate the growing population, especially among migrant workers who come to the area in search of high-season employment [81].

Another major environmental problem is the limited sewage system of the island. Only $62 \%$ of the Florianópolis population is provided with a sewage system. The rest of the population discharges their household and commercial wastewater into nature. The sea and lagoons have become highly vulnerable-particularly during the crowded peak tourism season [82]. In some popular beaches, seawater contains sewage-related biological waste that is causing both public and environmental health risks-e.g., in Canasvieiras.

Some attempts were made to address this issue. For instance, 'Floripa Se Liga Na Rede' is a program of the municipality, released in 2013 in partnership with the Catarinense Water and Sanitation Company (CASAN), which aims to promote the interconnection of real estate serviced by the public network of sewerage and to eliminate inadequacies in building installations [83]. The program targets $75 \%$ of the properties of the city-current coverage is $62 \%$.

Another challenge relates to planning and regulation hiccups. The 2014 Master Plan used, for the first time, the concept of sustainability to identify the goals and tools to be used to create a sustainable city by programs and incentives. The main goal is to preserve natural habitats and promote energy efficient design and equipment [81]. However, the plan disagrees with the environmental legislation involving prevention of natural disasters and does not correspond with local needs linked to population growth [84].

On top of the discharge of domestic and industrial waste, deforestation and irregular land occupation are the main problematic areas that impact marine ecosystem and fishery productivity, intensifying the impoverishment of fishermen and food security in fishing communities [85]. In order to minimize the predatory effects of fishing on sea turtles, the Tamar Project launched in 2005 its base in the region of Barra da Lagoa Beach, $25 \mathrm{~km}$ from the center of Florianópolis [86].

Florianópolis is the first city in Brazil to officially aim to become zero-waste. This movement provoked civil society and organizations-such as Interinstitutional Group of Solid Waste (GIRS), Commercial and Industrial Association of Florianópolis (ACIF), universities, civil entities and companies-to start a process of implementation of internal programs. Increasing sustainability awareness led society to demand from the government the establishment of a goal for the city, 
which was established to achieve a $90 \%$ diversion of landfill by 2030. Further raising this awareness is critical, as particularly the sustainability of the water environment of the city-given its island and lagoon nature-is under already serious threat [87].

\subsection{Institutional Development}

Following tourism success, during the last years the innovation and technology sector has been performing quite well in Florianópolis. Actors in the city were aware that innovation emerges as a result of co-creation between companies, citizens, universities, and government, in a context marked by the existence of partnerships, collaborative networks, and symbiotic relationships [88]. Despite this quadruple-helix model partnership being frequently pronounced in policy circles, 'walking the talk' is still a big challenge.

A limitation of knowledge-based urban development of Florianópolis is the lack of the innovation sector's political power and say on the city's governance and planning. This is a dichotomous situation as innovation and technology activities are major tax generators, but only a small portion of this tax is kept locally in Florianópolis. This is due to the governance system of Brazil, leaving municipalities with limited financial resources. State government, however, has been active in providing support for knowledge-based urban development of the city—e.g., funding and incentives for innovation centers and enterprises.

Universities have their own dynamics and are generally more receptive than active. IFSC and UFSC have considerably more access to funds for R\&D, but depending on the administration, at times there can be resistance in interacting with the private sector. Companies also receive guidance from business and industrial associations. The oldest association has been active for more than a century-Florianópolis Commercial and Industrial Association (ACIF). National associations for retail (CDL), accommodation (ABIHSC), entertainment (ABRASELSC), technology (ACATE), trade (FECOMERCIO), and industry (FIESC) opened their headquarters in Florianópolis.

Non-governmental organizations (NGOs) have been imprinting a culture of understanding on the city's problems. In 2005, FloripAmanhã was founded by a group of individuals aiming to contribute to strategies for sustainable development and building citizenship and social wellbeing. At the same time, ICOM was founded to promote community development by mobilizing, articulating, and supporting investors and social organizations. Since 2008, ICOM has been publishing an annual report called Sinais Vitais to inspire community participation and public debates.

A major governance challenge is providing safety and security. In parallel to elsewhere in Brazil, safety and security issues are at the forefront as they are highly impacting the lifestyle of everyone. The downward trend of the Brazilian economy since 2013 has had a tremendous impact on the crime rates. Florianópolis takes is share from this-although the city is still relatively much safer than elsewhere in Brazil. According to the State Department of Public Security, in Florianópolis, the homicide rate per 100,000 inhabitants is 11.7-an outcome of the bursting drug use and trafficking issue.

In Brazil, governments play a role in the creation of employment in the public sector. The reason for this is that providing employment (mostly low-income earners) would take those people from working for crime syndicates. While it serves the purpose of crime control, this creates a productivity problem for the public sector. Due to budgetary restrictions, the local government of Florianópolis faces serious difficulties in the generation of new jobs. Furthermore, according to the Ministry of Labor, 1510 formal jobs were lost in the city in 2017 as a result of the still incipient economic recovery of the services sector-that is, the city's flagship.

The city, however, still maintains one of the lowest unemployment rates among the national capitals due to higher-level income generating jobs in the technology sector, socioeconomic profile of a median-income city, and seasonal tourism sector jobs. In the first half of 2018, the average net monthly per capita income received was R\$3225 (about US\$775)—sixth among capitals, behind Vitória, Brasília, Porto Alegre, São Paulo, and Curitiba. This is explained by the high number of skilled knowledge workers-over $15 \%$ of employees have a university degree. 
Observatories for urban mobility, social and social innovation, connected to federal and state universities, have been created to provide open and collaborative platforms to strengthen such respective areas. Despite the importance of creating indicators and making the city's diagnosis and planning, thus, producing relevant enablers for good governance, there is still a trend to articulate these initiatives towards specific and segmented guidelines. On the other hand, public service is dealing with the recent idea of developing a culture of horizontal engagement between citizen and government, demanding a new public service.

Aligned with this concept, the Network of Public Spaces (REP) is a recent initiative from Florianópolis Urban Planning Institute (IPUF), aiming to integrate the strategies of planning, intervention, and management of the city's public spaces, building partnerships with the community. However, there is a major challenge for institutional effectiveness of projects. The ineffectiveness issue is not solely unique to local governments; political discontinuity, misconduct, and corruption have their roots in all three-tier governments. Every four years, when elections are due, the city replaces an average of 700 senior positions.

Corruption and misconduct are major problems for the whole of Brazil, hampering its socioeconomic development. The misconduct issue is also evident in Florianópolis. One example is the Hercílio Luz Bridge. This engineering masterpiece was built in 1926 and closed in 1991 for safety concerns. After almost three decades, the restoration works of the bridge-through a partnership of the federal, state, and local governments-is still in progress, as shown in Figure 9. The bridge has been the symbol of the city for two reasons-for 'high aesthetics' and 'poor governance' of the city.

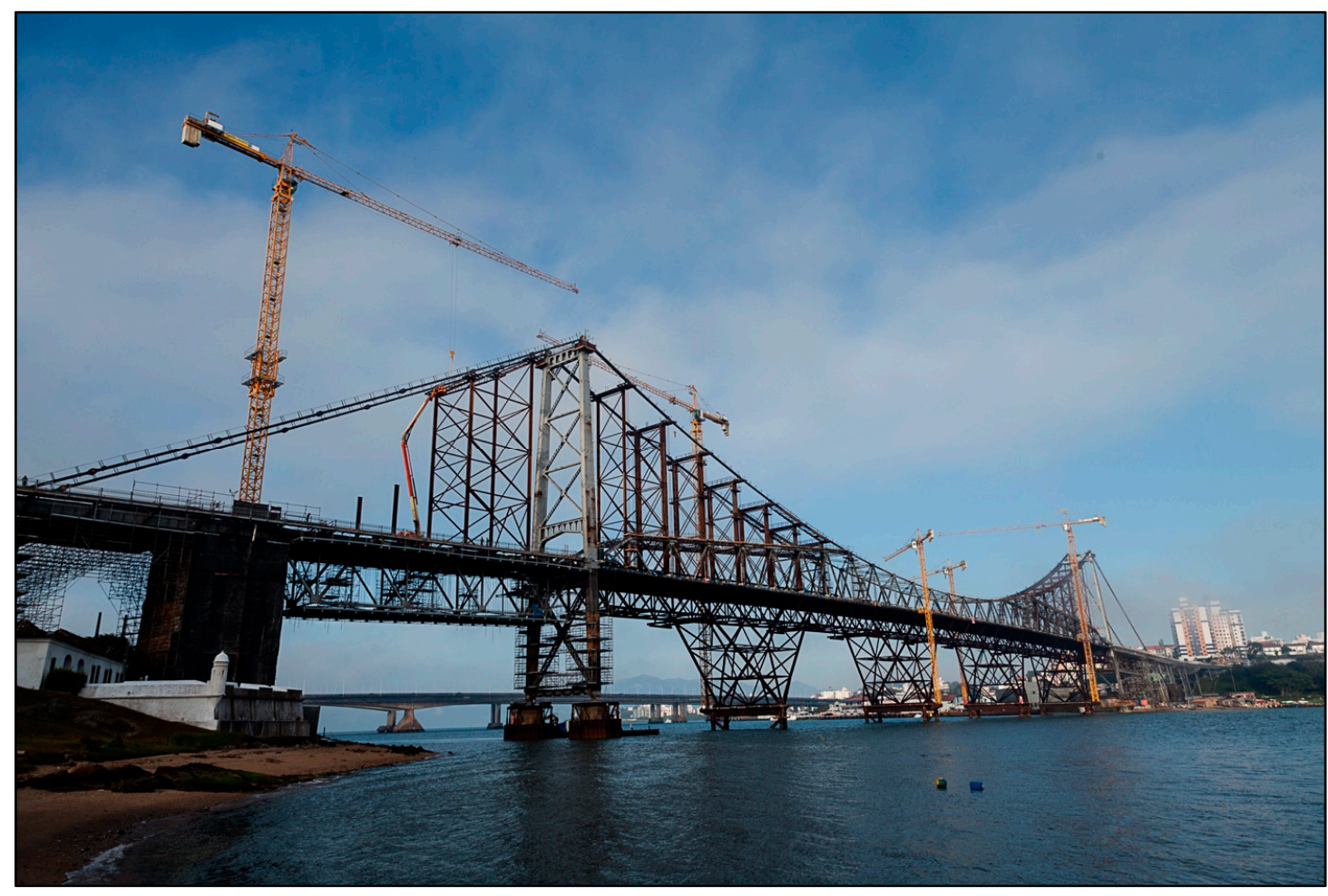

Figure 9. A view of the Hercílio Luz Bridge, reproduced with permission from Eduardo Trauer (photo taken in February 2018).

\subsection{Knowledge-Based Urban Development Progress and Challenges}

Its subtropical climate, island nature, pristine beaches, gourmet cuisine, and local culture transformed Florianópolis into a popular tourist destination in the 1990s. During recent years, an increasing concentration of high-tech companies provided an opportunity to turn Florianópolis into a smart innovation hub for Brazil. Today, Florianópolis is a prominent Brazilian city with ambitions 
to achieve thriving knowledge-based urban development and smart city transformation. Thus far, the city is recognized as an Innovation Capital of Brazil, and for some has the potential to become the 'Silicon Valley of South America' or 'Smart Floripa'.

The real challenge for the city, however, is finding a way to move the recognition of the city from a national level to international by placing it on the international map of innovation locations [89]. The city is willing to create a new path for a smart innovation island transformation to receive international attention. Its unique characteristics and achievements so far provide a possibility for developing such a pathway. However, these strengths and opportunities also come with counter weaknesses and challenges. For instance, Florianópolis has: (a) pristine but rapidly degrading natural environment; (b) existing but draining human capital; (c) increasing but inequitable income-levels; (d) diverse but incoherent community; (e) relative safety but raising serious security concerns; (f) numerous but conflicting planning schemes and regulations; and (g) established institutions but performing mostly ineffective governance.

The path Florianópolis takes in its journey from a tourist island to a smart innovation island is neither clear nor without major hurdles. Nevertheless, Florianópolis is still determined to achieve knowledge-based urban development and smart city transformation to realize such transformation. A priority seems to be so far given to making space and place for innovation companies and communities in the city. This approach is widely supported in the literature [90,91]. Likewise, some attempts also exist to create a smart innovation ecosystem-e.g., a municipal innovation system is currently being discussed-however, the complexity of governance mechanisms in such a smart innovation ecosystem is delaying the development process [92].

The findings of this study revealed the main prospects (or progress) and constraints (or challenges) in Florianópolis' knowledge-based urban development and smart city transformation journey. These findings are presented under the economic, societal, spatial, and governance domains in Tables 3 and 4. Additionally, the salient characteristics of the city in these development domains are presented in Appendix A, as shown in Table A1, and a timeline of Florianópolis' developmental milestones is illustrated in Appendix B, as shown in Figure A1.

Table 3. Florianopolis' knowledge-based urban development progress.

\begin{tabular}{|c|c|}
\hline \multicolumn{2}{|l|}{ Economy } \\
\hline Condition & Implication \\
\hline $\begin{array}{l}\text { Federal University of Santa Catarina (UFSC) research on } \\
\text { maricultural and government policy on tourism } \\
\text { and gastronomy }\end{array}$ & $\begin{array}{l}\text { - Development of gastronomic tourism along with the } \\
\text { sun-sand-sea tourism }\end{array}$ \\
\hline - UNESCO Creative City of Gastronomy recognition & - Strong motivation in and reputation of the city \\
\hline - Construction of event centers & - Expansion of tourism to off-season \\
\hline $\begin{array}{l}\text { - Tourism and gastronomy support institutions } \\
\text { and workforce }\end{array}$ & $\begin{array}{l}\text { Tourism performance improvement in the recent years } \\
\text { resulting in international recognition }\end{array}$ \\
\hline $\begin{array}{l}\text { - Technology and innovation companies that are locally } \\
\text { fostered or nationally attracted }\end{array}$ & $\begin{array}{l}\text { Extension of tourism activities to business and } \\
\text { event tourism }\end{array}$ \\
\hline $\begin{array}{l}\text { - Higher education system and several universities of } \\
\text { the city }\end{array}$ & $\begin{array}{l}\text { - Development of human capital and attraction of diverse } \\
\text { student community }\end{array}$ \\
\hline - $\quad$ Federal, state, and municipal legislation & - Promotion of innovation and technology sectors \\
\hline - Entrepreneurs and early technology adopters & - Blue Ocean Strategy formulation \\
\hline Government incentive programs & - Emerging innovation ecosystem \\
\hline - Unique nature and quality of life & - Attraction of visitors and talented knowledge workers \\
\hline \multicolumn{2}{|l|}{ Society } \\
\hline Condition & Implication \\
\hline $\begin{array}{l}\text { - Training availability generated employment opportunities } \\
\text { in tourism sector for unskilled residents }\end{array}$ & $\begin{array}{l}\text { - Positive contribution to employment levels resulting in } \\
\text { improved social texture }\end{array}$ \\
\hline
\end{tabular}


Table 3. Cont.

- Social protection networks provide help to the neediest-even though the support is limited it brings people above the poverty line

- The city is an attractive location to live and work particularly for Brazilians that are moving to the city from other states for various reasons

- The city has several social organizations committed to help the most vulnerable- even though the funds are limited their existence is crucial
- $\quad$ Slight improvement in the conditions of people living under poverty line, but the magnitude of the problem requires radical solutions

- Increasing inflow of migration from rest of the country bringing talent that is escaping from worsening safety conditions of elsewhere in Brazil

- The magnitude of social problems is huge; however, social organizations are making positive changes in some individuals' lives

Environment

Condition

- Perfect climate and natural beauty of the city

- Smart city has been pronounced in the city as a near future direction to follow-particularly there is a growing interest in smart city technologies

- Sustainability issue is at the forefront of policy discussions as it is critical for the future

- There are attempts to formalize some of the informal development-such as the UFSC campus-through new planning schemes

Implication

- Attracting visitors and inflow migration

- There have been some attempts in consideration of smart city technology, however, nothing concrete developed

- A zero-waste strategy has been adopted, however, it is too early to see the outcomes

- While legalizing some of the informal buildings it could lead future development to follow formal procedures and standards

Governance

Condition

Implication

- Specialized industry associations working diligently to address main issues

- Improvements in company networking and clustering along with access to training

- Despite budgetary limitations local government is trying hard to deliver basic municipal services-however, at times there occur some interruptions

- Brazilian motto of 'order and progress' highlighting where the attention needs to be paid-safety-security and socioeconomic progress-is adopted by the city

- Public sector was successful in creating and promoting the 'Magic Island' brand for the city, this was followed by the private sector initiative of the 'Innovation Capital of Brazil' brand

- Innovation route was a successful approach by the local government to link key innovation hubs

- Urban services and amenities are being delivered, even though they might not be timely and high quality at times

- In both order and progress issues the city is ahead of many other locations in Brazil-despite the achievements, they are not enough

- Brand helped tourist perceptions and sector to develop and grow; however, a similar support has not been officially provided for the 'Innovation Capital of Brazil' brand

- The route increased networking and face-to-face interaction of the knowledge workers

Table 4. Florianopolis' knowledge-based urban development challenges.

\begin{tabular}{|c|c|}
\hline Economy & \\
\hline Condition & Implication \\
\hline $\begin{array}{l}\text { - Low public investment and support in science, technology, } \\
\text { innovation, and innovation ecosystem }\end{array}$ & $\begin{array}{l}\text { - Hampering the growth potentials and keeping the } \\
\text { reputation at the national level }\end{array}$ \\
\hline $\begin{array}{l}\text { - Lack of an adequate policy to support talented } \\
\text { foreigner workforce }\end{array}$ & $\begin{array}{l}\text { - The city mostly being able to attract talent from Brazil and } \\
\text { Latin America }\end{array}$ \\
\hline $\begin{array}{l}\text { - Lot of work to be done for actors joining forces towards } \\
\text { common goals, including sustainable economic activities }\end{array}$ & $\begin{array}{l}\text { - Lack of a commonly agreed roadmap to achieve } \\
\text { international reputation }\end{array}$ \\
\hline $\begin{array}{l}\text { - Lack of a big picture view thinking and required actions to } \\
\text { turn city into a global innovation hub }\end{array}$ & $\begin{array}{l}\text { - City reputation as an innovation island to remain in the } \\
\text { national context only }\end{array}$ \\
\hline $\begin{array}{l}\text { Delays in establishing and putting an effective innovation } \\
\text { ecosystem in place }\end{array}$ & $\begin{array}{l}\text { Development not being planned and unable to foster, } \\
\text { attract, and retain talent and investment }\end{array}$ \\
\hline $\begin{array}{l}\text { The link between economic success and smart-sustainable } \\
\text { development has not been clearly placed into practice }\end{array}$ & $\begin{array}{l}\text { Economy is advancing with ad hoc policies and practices, } \\
\text { rather than with a conceptual framework of planned smart } \\
\text { and sustainable economic progress }\end{array}$ \\
\hline \multicolumn{2}{|l|}{ Society } \\
\hline Condition & Implication \\
\hline $\begin{array}{l}\text { - Socio-spatial segregation and inequality due to lack of } \\
\text { social development and cohesion }\end{array}$ & - Decreasing community values and increasing inequality \\
\hline
\end{tabular}


Table 4. Cont

Society

Condition

Implication

- Socio-spatial segregation and inequality due to lack of social development and cohesion

- Inflow of low-income groups and not offering world-clas education and skill development opportunities

- Limited support to the social protection networks

- Gentrification and inflow of middle/high income groups

- Worsening social conditions, including crime levels and economic recession

- While diversity in the community can be seen as an advantage, a clear socioeconomic gap exists between them

- Decreasing community values and increasing inequality

- Contributing to the social disintegration problem and relatively lower education and training outcomes

- Demand for further support or radical solutions

- Weakening of cohesive community

- Brain drain to overseas and very low levels of brain gain back

- Social cohesion is far from a reality, only during the carnival and football games and at beaches does society look united and cohesive

Environment

Condition

- High population growth rate with lack of world-class urban infrastructure

- Informal and favela developments

- Increasing urbanization rate

- High inoccupancy housing rates despite of high housing demand

- $\quad$ Significant difference between peak summer tourism season and the rest of the year

- Informal land occupation

- Housing deficit due to unavailability of providing land for demand

- Control of deforestation and irregular occupation due to poor conservation practice

- Lack of basic sanitation practice

- Lack of efficient public transport system and high accident levels in a private motor vehicle dependent city

- Poor and unsustainable transport infrastructure that brings traffic to standstill during the peak hours and peak tourism season

\section{Implication}

- Adding on to the existing infrastructure and sustainability challenges

- Development with low standards and quality

- Threat to the natural ecosystems

- Unsafe neighborhoods and rapidly weakening social functions

- Overcapacity of roads, water, power, and sewerage during the peak season

- Undermined environmental conservation/protection

- Growth of informal housing settlements in risky or environmentally significant areas

- At odds with existing environmental legislation-showing weakness at control and protection

- Pollution of rivers, sea, lagoons, and beaches

- Serious mobility and accessibility problems, high casualty accidents, unsafe city for cycling

- Highly limits the mobility in the city, even including emergency services; hampers tourism as tourists cannot easily explore the island

Governance

Condition

Implication

- Limited public, private, academia, community partnerships-quadruple-helix partnership

- Limited interdisciplinary and transdisciplinary research of local universities

- Top university of the city lacks international reputation education and skill development systems are below world-class

- Lack of transparency, red tape, corruption in government practice and lobbying of influential organizations and individuals

- Downturn of the economy since the end of the boom in early $2010 \mathrm{~s}$

- Limited state government financial support to science, technology, and innovation

- Lack of an official city innovation ecosystem and roadmap

- Lack of an adequate government policy to support talented foreigner workforce

- Lack of strategic vision in the planning mechanism and plan and policy implementation

- Lack of development control and demolition power of the informal structures

- Decreased effectiveness of plans and actions requiring broader collaboration

- Limited innovativeness and university-industry collaboration

- UFSC's international university ranking is only 751 and has no research collaboration with global top-50 universities

- Limited ability of government to address local issues adequately due to poor, ineffective, and non-transparent governance

- Increasing poverty and resulting unrest and sky rocketing crime rates

- Growth in the innovation sector is at a slow pace and lack of substantial incentives

- Planning of actions for the innovation sector growth is at best ad-hoc

- Highly limited attraction rate of foreign talent and resulting limited foreign direct investment

- Having ineffective plans and regulations, at times conflicting with each other

- Encouraging informal developments and land speculation 
The study discloses three key policy priorities for each of the development domains. In terms of economic development, the top three priorities are: (a) investing in science, technology, and innovation; (b) creating an effective and efficient urban innovation ecosystem; (c) fostering sustainable and knowledge-based economic activities. In terms of societal development, the top three priorities are: (a) promoting social development and community cohesion; (b) establishing social protection networks particularly for the neediest; (c) improving the quality of the education, learning, and skill development system. In terms of spatial development, the top three priorities are: (a) conserving the pristine ecosystems of the island; (b) building world-class smart urban infrastructure; (c) establishing sustainable development and particularly sustainable mobility. In terms of institutional development and governance, the top three priorities are: (a) building effective, participatory, and transparent governance practice and support mechanisms; (b) planning strategically and acting upon for a timely implementation; (c) enabling quadruple-helix partnerships in key projects.

In the light of the research findings, the study also proposes Florianópolis to adopt a locally customized framework of knowledge-based urban development-where it can be used as a powerful instrument to facilitate an urban turnaround, bring prosperity and sustainability to the city, and form the geographies of disruption-such as smart cities and innovation districts [93]. This framework builds on the generic knowledge-based urban development framework presented in Figure 2, and specifically identifies the critical attributes-i.e., the top priorities in each domain-that are particularly required to put Florianópolis on the way to a thriving transformation towards a smart innovation island. Figure 10 illustrates this locally-customized framework.

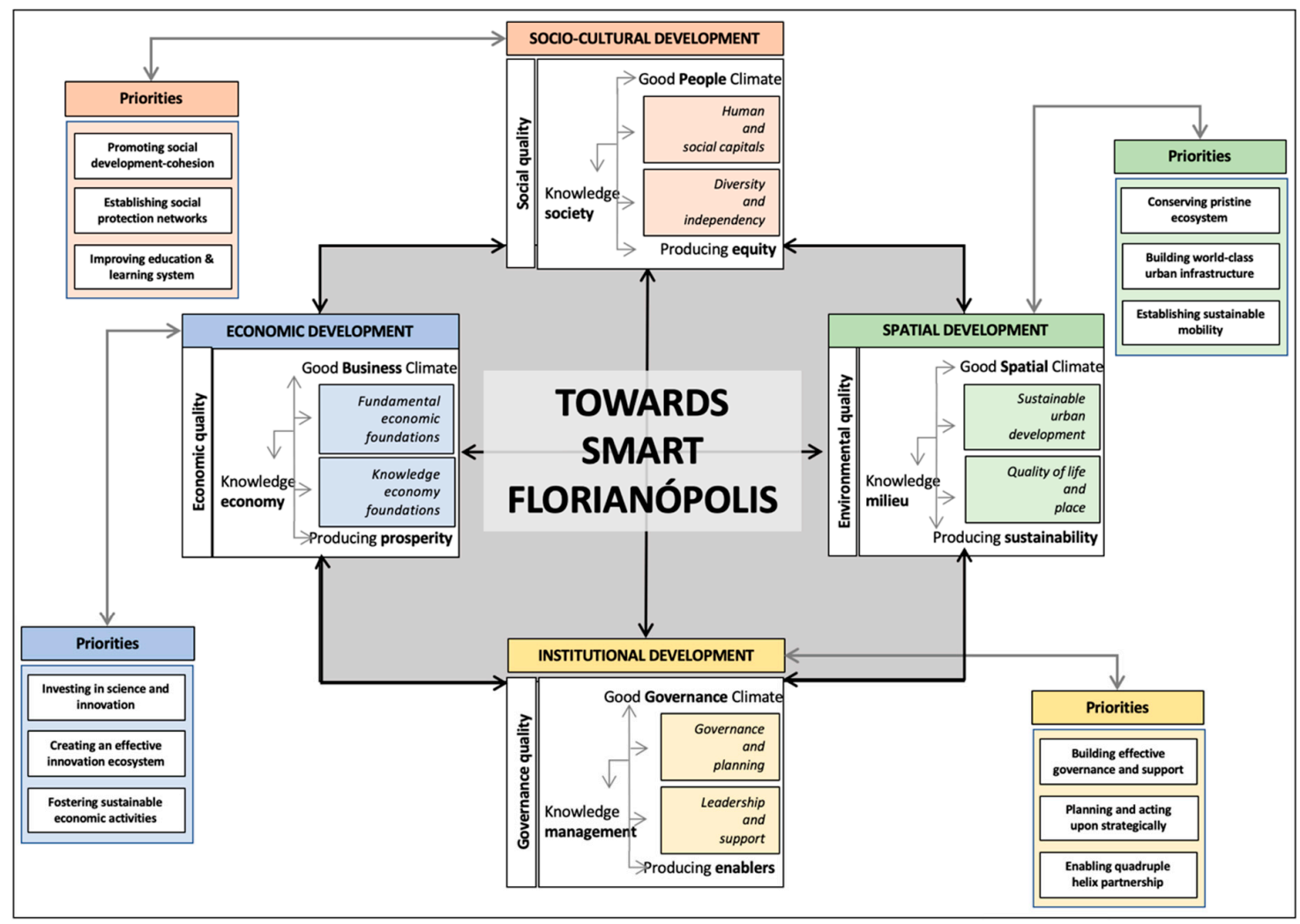

Figure 10. A framework for knowledge-based development of Florianópolis, derived from Reference [46].

\section{Discussion and Conclusions}

This paper focused on addressing the question of 'what it takes to transform a tourist island into an innovation capital' by placing Florianópolis-a.k.a. Smart Floripa-under the knowledge-based urban development microscope. The results of the study acknowledged the recent achievements of the city in 
establishing a promising innovation hub/capital for the nation, and by doing so diversifying the local economy-with inclusion of newly created knowledge-based activities to the traditionally dominant tourism and public service ones. Even though the accomplishments are to a level commendable, as shown in Table 3, the study also highlighted a large number of major challenges and their potential implications that the city needs to tackle without much delay, as shown in Table 4.

In sum, the findings suggested that particularly the municipal planning for the near-term needs to seek solutions to the most urgent problems-such as those related to environmental conservation, public security, urban mobility, and infrastructural improvements-and they need to be novel and sustainable solutions. The city has also a willingness to adopt technological tools as part of the smart solution. However, given the budgetary limitations and ongoing deficits in governmental agencies, urban administrators should keep in mind that smart city technology does not necessarily need to be new to be effective. Particularly in the developing country cities-such as Florianópolis-the most effective solutions often involve innovative uses of existing technologies at low cost [94]. The findings of the study also pointed out the serious governance hiccups of the nation that infiltrate into the state and municipal level politics as the biggest challenge to deal with.

While the knowledge-based activities are promising in Florianópolis, the same cannot be said for Brazil. For instance, the Global Innovation Index 2018 ranked Brazil as the 64th nation out of 126 [93]. This figure gets even worse when Brazil is compared with OECD countries-37th out of 37 , the weakest performance. A closer look at the indicators of the index highlights the areas where performance is particularly suffering. In the following areas Brazil is ranked outside the top-80 nations: (a) political environment; (b) business environment; (c) tertiary education; (d) general infrastructure; (e) credit; (f) investment; (g) knowledge impact; (h) creative goods and services [95]. Unfortunately, Florianópolis also shows similar weaknesses in most of these areas-indicating a national path dependency.

The challenges are great for Florianópolis, but the path to solutions, from the identification of bottlenecks to the specifications of policy directions, has already been found. Putting them into action with a good governance practice is now required, which is the greatest challenge in any locality in Brazil. Brazil's National Museum's recent fire disaster in Rio de Janeiro is an example of poor management/governance practices of the authorities. Almost the entire collection of Latin America's largest museum and 200 years of work was burned to ashes. The collection was not insured, no smoke detectors were installed, and fire hydrants ran out of water. Nevertheless, Florianópolis is willing to address the governance challenges and showcase an exemplar performance. Is this willingness enough? Only time will tell.

Florianópolis achieved its goal of becoming a tourist island in the 1990s. In recent years, it has become the innovation capital of Brazil. Recently for the city, becoming a smart and sustainable city seems to be the next goal. However, this is the most challenging target the city has ever chosen for itself. The reason for this is simple; becoming smart and sustainable requires the entire city to meet this target. In other words, more or less only having natural beauty could lead to a success story in tourism. Similarly, in isolated exclusive locations of a city innovation activities could be performed and this could also lead to a recognition or claiming success in this area. However, a smart and sustainable city is a different animal. The achievements in this type of city require success in all knowledge-based urban development domains-economy, society, environment, and governance. Besides, these cities are inclusive and resilient $[96,97]$. Furthermore, the recent election of Brazil's new far-right president-Jair Bolsonaro-will likely inflate the sustainability related problems across the nation (and even globally). For instance, his views on the exploitation of the Amazon rainforest-often called the 'Lungs of the World' as it produces more than $20 \%$ of the world's oxygen-has already created serious concerns. The top-level political climate change denial rhetoric, and associated actions and malpractices will have inevitable consequences on Florianópolis' progress as well as the entire nation.

The results of this case report disclosed that despite some knowledge-based urban development achievements, Florianópolis' is currently neither 'smart' nor 'sustainable'. In the light of this finding, we suggest the use of a more realistic brand for the city: 'Towards Smart Florianópolis' 
or 'Towards Smart Floripa'. Moreover, adoption of a customized knowledge-based urban development framework — such as in Figure 10-would also be useful to the city to strategically plan its priorities for development. The findings also revealed insights on the new path creation processes and attempts of Florianópolis. In other words, the recipe of what it takes to transform a tourist island into an innovation capital has been disclosed. These insights are useful for local authorities and stakeholders of Florianópolis to consider and develop new strategies and find implementation grounds for a smart transformation. Furthermore, the insights might also be helpful for other developing country or emerging economy locations-aiming for aspiring knowledge-based urban development and smart city transformation along with generating socioeconomic and spatial resilience and good governance. Tourist cities or islands with similar characteristics could particularly benefit the most from the experiences of Florianópolis - even though the journey to a smart city has only just began, and there is a long and tough road ahead for Florianópolis.

Overall, this is a pioneering study, as it scrutinized the development journey of an ambitious city-that is constantly seeking to progress further-thoroughly from the lens of a knowledge-based urban development paradigm by engaging key local actors in the investigation. This paper revealed invaluable insights particularly into: (a) how to determine the strengths and weaknesses of a city by using a knowledge-based urban development framework; (b) how to engage key actors to discuss issues around the future development of their city as a smart, sustainable, and knowledge-based one; and (c) how to develop a customized framework for the knowledge-based development of a city to guide its future policy and actions. The learnings from the experiences of Florianópolis, and abovementioned insights, can inform the policymaking circles in Florianópolis, and other cities.

The following limitations of the study should also be considered while interpreting the findings: (a) the literature search could only find a moderate number of writings on the city and its relevant developmental issues; (b) the analysis conducted is descriptive and qualitative in nature, no thorough statistical elaborations were carried out; (c) there might be some possible unintended bias in conducting interviews with focus group members, the process of data analysis, and the method of data collection; (d) while public and academic sectors' inputs were collected directly, private sector's voices were only captured indirectly through the non-governmental organizations that participated in the study, and community perceptions were not considered; (e) a relatively moderate but acceptable number of local actors participated in the study, their potential unconscious bias might have affected the results. Our prospective studies will focus on addressing these limitations, and conducting further empirical investigations - by using both qualitative and quantitative techniques to measure the innovation and smartness performance of the city in comparative studies. Furthermore, our future research will also concentrate on developing a comprehensive 'smart city strategy' for the city to guide Florianópolis' smart and sustainable urbanism endeavors.

Author Contributions: T.Y. designed and led the research; T.Y., J.S.-M., A.F., C.L., N.B., T.W., and T.S. jointly prepared the manuscript; T.Y. and A.F. revised the manuscript. All authors read and approved the final version of the manuscript.

Funding: This research is an outcome of a project entitled 'Smart Floripa: Strategizing the Transformation of Florianópolis into a Smart Innovation Island'. The project received financial and in-kind support from the following project partners: Governo do Estado de Santa Catarina, Prefeitura Municipal de Florianópolis, Fecomércio Santa Catarina, Senac Santa Catarina, Associação Brasileira das Empresas de Software, Instituto Lixo Zero Brasil, Federal University of Santa Catarina, University of Caxias do Sul, and Queensland University of Technology.

Acknowledgments: The authors cordially thank: abovementioned project partners for the financial and in-kind support; focus group participants for sharing their invaluable knowledge and time; Eduardo Trauer and Eduardo Zappia for taking photographs used in the manuscript; Susan Yigitcanlar for native speaker English editing of the manuscript; the managing editor of the journal and four anonymous referees for their constructive comments on an earlier version of the manuscript.

Conflicts of Interest: The authors declare no conflict of interest. 


\section{Appendix A}

Table A1. Salient characteristics of Florianopolis, collected from various data sources.

\begin{tabular}{|c|c|c|c|c|}
\hline Domain & Characteristic & Description & Value & Unit \\
\hline \multirow{6}{*}{ Geo-demographic } & Population & Total resident population & 453,285 & $\mathrm{ppl}$ \\
\hline & Area & Total area $\mathrm{r}$ & 436.5 & $\mathrm{~km}^{2}$ \\
\hline & Density & Population density & 1038.45 & $\mathrm{ppl} / \mathrm{km}^{2}$ \\
\hline & Age & Median age & & years \\
\hline & Climate & Climate category & subtropical & type \\
\hline & Economy & Dominant economic sector & service & type \\
\hline \multirow{8}{*}{ Economic development } & Gross domestic product & Gross domestic product (GDP) per capita & 39,678 & $\mathrm{R} \$$ \\
\hline & Major companies & Number of top-100 Brazilian companies hosted & & count \\
\hline & Foreign direct investment & Ratio of international share in foreign direct investments & 0.375 & ratio \\
\hline & Urban competitiveness & Urban competitiveness index ranking & 9th & national rank \\
\hline & Innovation economy & City ranking in innovation economy & 3rd & national rank \\
\hline & Research and development & Ratio of research and development expenditure in GDP & 0.002 & ratio \\
\hline & Patent applications & Patent cooperation treaty patent applications per million inhabitants & 0.110 & ratio \\
\hline & Knowledge worker pool & Ratio of professionals and managers in all workers & 0.152 & ratio \\
\hline \multirow{8}{*}{ Societal development } & Education investment & Ratio of public spending on education in GDP & 0.045 & ratio \\
\hline & Professional skill base & Ratio of $18+$ years old people with tertiary education (bachelor degree or above) & 0.163 & ratio \\
\hline & University prestige & Ranking of the local top ranked university (UFSC) & 751st/9th & inter/national rank \\
\hline & Mobile broadband & Ratio of mobile broadband subscribers in $18+$ years old population & 0.546 & ratio \\
\hline & Cultural diversity & Ratio of people that were born abroad & 0.008 & ratio \\
\hline & Social cohesion and equality & Level of income inequality (Gini coefficient) & 0.547 & ratio \\
\hline & Socio-economic dependency & Ratio between the elderly population and the working age (15-64 years) & 0.340 & ratio \\
\hline & Unemployment level & Unemployment rate & 0.075 & ratio \\
\hline \multirow{8}{*}{ Spatial development } & Smart city formation & City ranking in smart city achievements & 6th & national rank \\
\hline & Sustainable transport use & Ratio of sustainable transport mode use in commuting population & 0.010 & ratio \\
\hline & Environmental impact & Per capita carbon dioxide emissions & 2.17 & $\mathrm{tCO}_{2} \mathrm{e} / \mathrm{ppl}$ \\
\hline & Urban form & Ratio of informal buildings in all buildings & 0.504 & \\
\hline & Quality of life & City ranking in quality of life & 2nd & national rank \\
\hline & Cost of living & City ranking in cost of living & 8th & national rank \\
\hline & Housing affordability & Ratio of GDP per capita to median dwelling price & 0.073 & ratio \\
\hline & Personal safety & City ranking in personal safety & 70th & national rank \\
\hline \multirow{8}{*}{$\begin{array}{l}\text { Institutional } \\
\text { development }\end{array}$} & Government effectiveness & Level of government effectiveness in achieving knowledge-based urban development & low & Likert-scale \\
\hline & Electronic governance & Level of online applications for public services (vote, tax, payment, renewal) & low & Likert-scale \\
\hline & Strategic planning & Level of knowledge-based urban development strategies in strategic development plans & none & Likert-scale \\
\hline & City branding & Level of deliberately created city branding and resulting reputation & medium & Likert-scale \\
\hline & Effective leadership & Level of institutional leadership in overseeing knowledge-based urban development & none & Likert-scale \\
\hline & Strategic partnership & Level of effective triple-helix and public-private-partnerships & medium-low & Likert-scale \\
\hline & Community engagement & Level of institutional mechanisms for community development and participation & medium-low & Likert-scale \\
\hline & Infrastructure and amenities & Level of effective infrastructure and amenity development and maintenance & medium-low & Likert-scale \\
\hline
\end{tabular}




\section{Appendix B}

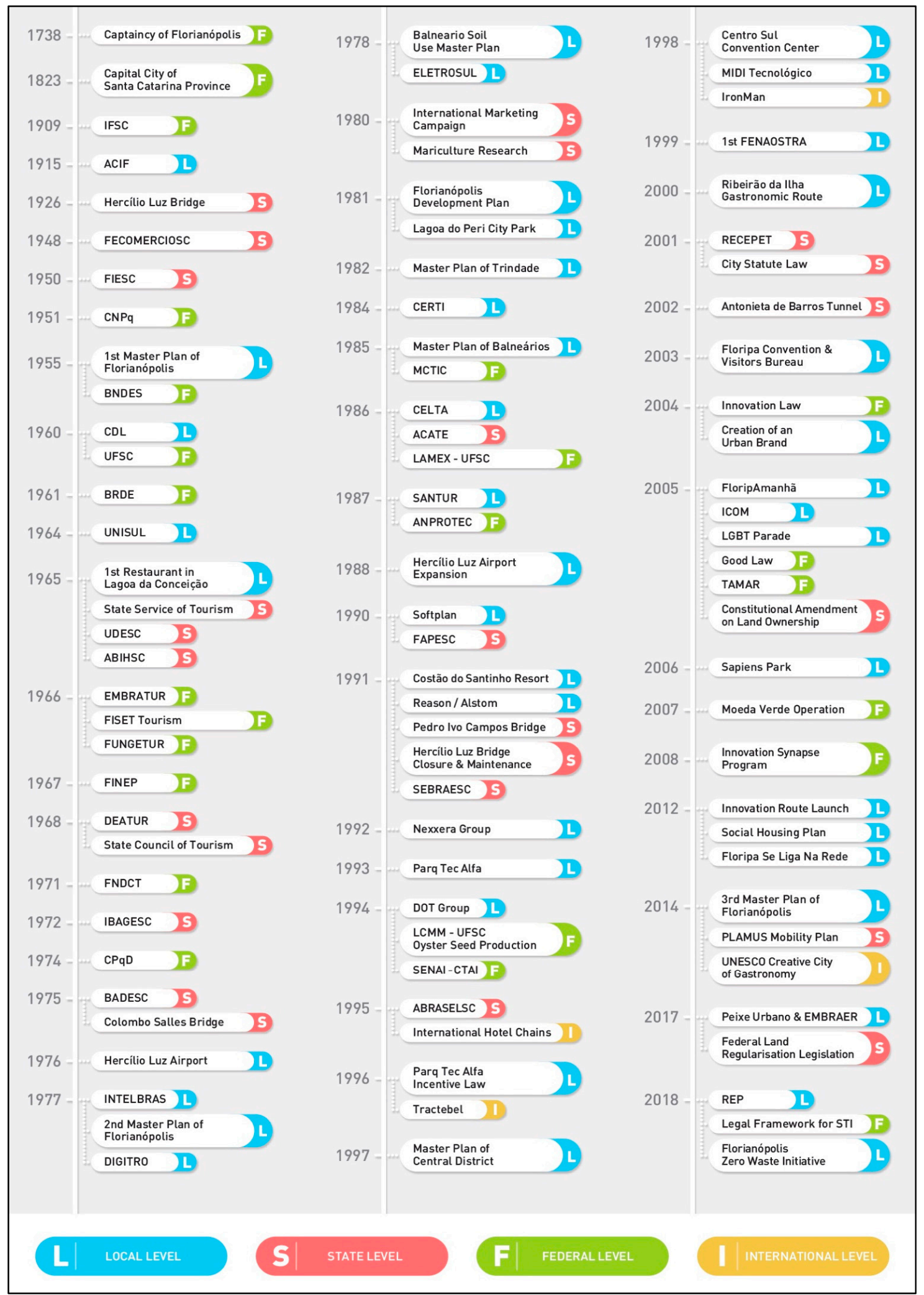

Figure A1. Timeline of Florianopolis' developmental milestones, authors' own compilation. 


\section{Appendix C}

Table A2. Reviewed literature.

\begin{tabular}{|c|c|}
\hline No & Literature \\
\hline [8] & $\begin{array}{l}\text { Zouain, D.M.; Plonski, G.A. Science and technology parks: Laboratories of innovation for urban development-an approach from } \\
\text { Brazil. Triple Helix 2015, 2, 7, doi:10.1186/s40604-015-0018-1. }\end{array}$ \\
\hline [29] & $\begin{array}{l}\text { Irufi, A.M.; Haddad, E.A.; Nijkamp, P. Industrial scope of agglomeration economies in Brazil. Ann. Reg. Sci. 2016, 56, 707-755, } \\
\text { i:10.1007/s00168-016-0768-3. }\end{array}$ \\
\hline [35] & $\begin{array}{l}\text { Guerra, J.; Knabben, J.; Fernandez, F.; Bailey, C.; Barbosa, S.; Neiva, S. Reprint of: The adoption of strategies for sustainable } \\
\text { cities: A comparative study between Newcastle and Florianópolis focused on urban mobility. J. Clean. Prod. 2017, 163, } \\
\text { S209-S222, doi:10.1016/j.jclepro.2017.05.142. }\end{array}$ \\
\hline [37] & $\begin{array}{l}\text { Michelmann, A.C. Franklin Cascaes, a Divulgação Turística de Florianópolis e a Invenção da ‘llha da Magia’. Unpublished } \\
\text { Bachelor Thesis, Federal University of Santa Catarina, Florianópolis, Brazil, } 2017 .\end{array}$ \\
\hline [38] & $\begin{array}{l}\text { Azevedo, I.; Teixeira, C.; Teixeira, M. CELTA e MIDI Tecnológico: Um estudo de caso das incubadoras de Florianópolis. In } \\
\text { Proceedings of the International Congress on Research \& Development, Curitiba, Brazil, 21-23 September 2016; pp. 347-363. }\end{array}$ \\
\hline [49] & $\begin{array}{l}\text { Lenzi, M.H. A Invenção de Florianópolis Como Cidade Turística: Discursos, Paisagens e Relações de Poder. Unpublished } \\
\text { Doctoral Thesis, University of São Paulo, São Paulo, Brazil, } 2016 .\end{array}$ \\
\hline [50] & $\begin{array}{l}\text { Pereira, E.M. A importância de conceitos modernistas no planejamento urbano de Florianópolis. Seminário de Historia da Cidade e } \\
\text { do Urbanismo } \mathbf{2 0 0 0}, 6,1-15 \text {. }\end{array}$ \\
\hline
\end{tabular}

[51] Machado, E.V. Florianópolis: Um Lugar em Tempo de Globalização. Unplublished Doctoral Thesis. Federal University of Santa Catarina, Florianópolis, Brazil, 2000.

[52] Barreto, M.; Burgos, R.; Frenkel, D. Turismo, Políticas Públicas e Relações Internacionais; Papirus: Campinas, Brazil, 2003; ISBN 8530807154 .

[53] Oliveira, A.P. A História do Turismo em Florianópolis Narrada por Quem a Vivenciou (1950-2010); Palavracom Editora: Florianópolis, Brazil, 2011; ISBN 9788564034051.

[54] De Luca Filho, V. A Geografia das Feiras de Negócios em Santa Catarina: Origem, Evolução e Dinâmica das Transformações. Unpublished Doctoral Thesis, Federal University of Santa Catarina, Florianópolis, Brazil, 2014.

[55] Santos, F.M.; Pereira, R.M. A rede hoteleira no núcleo urbano central de Florianópolis: Expansão urbana e turismo. In Proceedings of the IV Mercosur Tourism Research Seminar, Caxias do Sul, Brazil, 7-8 July 2006; pp. 1-15.

[56] Paulilo, M.I. Maricultura e território em Santa Catarina, Brasil. Geosul 2002, 17, 87-112.

[57] Azevedo, I.; Teixeira, C. Florianópolis: Uma análise evolutiva do desenvolvimento do desenvolvimento inovador da cidade a partir do seu ecossistema de inovação. REAVI 2017, 6, 108-121, doi:10.5965/2316419006092017108.

[59] Xavier, M. Polo Tecnológico de Florianópolis: Origem e Desenvolvimento; Insular: Florianópolis, Brazil, 2010; ISBN 9788574744957.

[64] Tarachucky, L. Sistematização da Aplicação do Brand DNA Process No Design de Marca de Cidades Criativas: Caso Projeto Rota da Inovação. Unpublished Master Thesis. Federal University of Santa Catarina, Florianópolis, Brazil, 2015.

[67] Ueno, A. A Concepção de um Modelo de Empreendedorismo Inovador Baseado em Conhecimento: Um Estudo de Caso do Programa Sinapse da Inovação. Unpublished Master Thesis, Federal University of Santa Catarina, Florianópolis, Brazil, 2011.

[68] Depine, A.C. Fatores de Atração e Retenção da Classe Criativa: O Potencial de Florianópolis Como Cidade Humana Inteligente Unpublished Master Thesis. Federal University of Santa Catarina, Florianópolis, Brazil, 2016.

[69] Fernandes, E. The legalisation of favelas in Brazil: Problems and prospects. Third World Plan. Rev. 2000, 22, 167, doi:10.3828/twpr.22.2.f765q34rm4600773.

[70] Prefeitura Municipal de Florianópolis (PMF). Municipal Plan of Housing of Social Interest of Florianópolis; PMF: Florianópolis, Brazil, 2012.

[71] Prefeitura Municipal de Florianópolis (PMF). Florianópolis Sustainability Action Plan; PMF: Florianópolis, Brazil, 2017.

[73] Prefeitura Municipal de Florianópolis (PMF). Florianópolis Urban Growth Study; PMF: Florianópolis, Brazil, 2017.

[74] Prefeitura Municipal de Florianópolis (PMF). Florianópolis Mitigation and Climate Change Study; PMF: Florianópolis, Brazil, 2017.

[75] Oliveira-Musse, J.: Homrich, A.S.; Mello, R.; Carvalho, M.M. Applying backcasting and system dynamics towards sustainable development: The housing planning case for low-income citizens in Brazil. J. Clean. Prod. 2018, 193, 97-114, doi:10.1016/j.jclepro.2018.04.219.

[81] Bridges, A. Leveraging Amenity-Led Growth and Collective Action for Sustainable Development in Florianópolis, 1965-2016. Unpublished Doctoral Thesis, Rutgers University, New Brunswick, NJ, USA, 2017.

[82] Scherer, M.E.; Asmus, M.L. Ecosystem-based knowledge and management as a tool for integrated coastal and ocean management: A Brazilian initiative. J. Coast. Res. 2016, 75, 690-694, doi:10.2112/SI75-138.1.

[83] Prefeitura Municipal de Florianópolis (PMF). Floripa Se Liga Na Rede; PMF: Florianópolis, Brazil, 2013.

[84] Figueiroa, A.; Scherer, M. Para onde estamos indo? Uma avaliação do plano diretor do Município de Florianópolis para o entorno da Estação Ecológica de Carijós. Desenvolvimento e Meio Ambiente 2016, 38, 283-301, doi:10.5380/dma.v38i0.47110.

[85] Bastos, G. Análise Financeira das Pescarias de Pequena escala No Município de Florianópolis. Unpublished Doctoral Thesis,
University of São Paulo, São Paulo, Brazil, 2009.

[85] Bastos, G. Análise Financeira das Pescarias de Pequena escala No Município de Florianópolis. Unpublished Doctoral Thesis,
University of São Paulo, São Paulo, Brazil, 2009.

[86] Stahelin, G.D.; Fiedler, F.N.; Lima, E.P.; Sales, G.; Wanderlinde, J. Projeto Tamar's station in Florianópolis, State of Santa Catarina, Southern Brazil. Mar. Turt. Newslett. 2012, 133, 23.

[98] Lara, A.P.; Marques, J.S.; Santos, N.; Costa, E.M. Projeto Florip@ 21: A construção de uma região inteligente na cidade de Florianópolis, Brasil. In Proceedings of the XV Latin Iberian-American Congress on Management of Technology, Porto, Portugal, 27-31 October 2013; pp. 1673-1691.

[99] Lorenzetti, J.; de Lima Trindade, L.; Pires de Pires, D.E.; Souza Ramos, F.R. Tecnologia, inovação tecnológica e saúde: Uma reflexão necessária. Texto \& Contexto Enfermagem 2012, 21, 432-439.

[100] Martins, C. O Papel das Incubadoras de Empresas do Polo Tecnológico de Florianópolis No Desenvolvimento do Processo de Empreendedorismo Inovador. Unpublished Master Thesis, Universidade do Sul de Santa Catarina, Florianópolis, Brazil, 2013.

[101] Sarquis, A.B.; Fiates, G.G.; Hahn, A.K.; Cavalcante, F.R. Empreendedorismo inovador no polo tecnológico de Florianópolis. REEN 2014, 7, 228-255, doi:10.19177/reen.v7e32014228-255.

[102] Gaspar J.V.; Menegazzo, C.; Fiates, J.E.; Teixeira, C.S.; Gomes, L.S. A revitalização de espaços urbanos: O case do Centro Sapiens em Florianópolis. Revista Livre de Sustentabilidade e Empreendedorismo 2017, 29, 183-205.

[103] Menezes, A.G.; Lezana, Á.G.; de Abreu-Ronconi, L.F.; de Oliveira-Menezes, E.C.; de Melo, É.N. A pesquisa-ação como estratégia de avaliação da inovação social: Estudo de uma entidade educacional do município de Florianópolis. NAVUS Revista de Gestão e Tecnologia 2016, 6, 93-105. 


\section{References}

1. Simmie, J.; Martin, R. The economic resilience of regions: Towards an evolutionary approach. Camb. J. Reg. Econ. Soc. 2010, 3, 27-43. [CrossRef]

2. Briguglio, L.; Cordina, G.; Farrugia, N.; Vella, S. Economic vulnerability and resilience: Concepts and measurements. Oxf. Dev. Stud. 2009, 37, 229-247. [CrossRef]

3. Yigitcanlar, T. Planning for smart urban ecosystems: Information technology applications for capacity building in environmental decision making. Theor. Empir. 2009, 4, 5-21.

4. Yigitcanlar, T.; Dizdaroglu, D. Ecological approaches in planning for sustainable cities: A review of the literature. Glob. J. Environ. Sci. Manag. 2014, 1, 159-188. [CrossRef]

5. Ghaderi, Z.; Som, A.P.; Henderson, J.C. Tourism crises and island destinations: Experiences in Penang, Malaysia. Tour. Manag. Perspect. 2012, 2, 79-84. [CrossRef]

6. Scheyvens, R.; Momsen, J. Tourism in small island states: From vulnerability to strengths. J. Sustain. Tour. 2008, 16, 491-510. [CrossRef]

7. Hadjimanolis, A.; Dickson, K. Development of national innovation policy in small developing countries: The case of Cyprus. Res. Pol. 2001, 30, 805-817. [CrossRef]

8. Zouain, D.M.; Plonski, G.A. Science and technology parks: Laboratories of innovation for urban development-an approach from Brazil. Triple Helix 2015, 2, 7. [CrossRef]

9. Jones, C.; Munday, M. Exploring the environmental consequences of tourism: A satellite account approach. J. Travel Res. 2007, 46, 164-172. [CrossRef]

10. Cooke, P.; Leydesdorff, L. Regional development in the knowledge-based economy: The construction of advantage. J. Technol. Transf. 2006, 31, 5-15. [CrossRef]

11. Evers, H.D.; Gerke, S.; Menkhoff, T. Knowledge clusters and knowledge hubs: Designing epistemic landscapes for development. J. Knowl. Manag. 2010, 14, 678-689. [CrossRef]

12. Cassingena-Harper, J.; Georghiou, L. The targeted and unforeseen impacts of foresight on innovation policy: The eFORESEE Malta case study. Int. J. Foresight. Innov. Policy 2005, 2, 84-103. [CrossRef]

13. Cabrer-Borras, B.; Serrano-Domingo, G. Innovation and R\&D spillover effects in Spanish regions: A spatial approach. Res. Pol. 2007, 36, 1357-1371. [CrossRef]

14. Chertow, M.R.; Ashton, W.S.; Espinosa, J.C. Industrial symbiosis in Puerto Rico: Environmentally related agglomeration economies. Reg. Stud. 2008, 42, 1299-1312. [CrossRef]

15. Yigitcanlar, T.; Inkinen, T.; Makkonen, T. Does size matter? Knowledge-based development of second-order city-regions in Finland. DISP 2015, 51, 62-77. [CrossRef]

16. Yigitcanlar, T. Technology and the City: Systems, Applications and Implications; Routledge: New York, NY, USA, 2016; ISBN 9781317575696.

17. Baum, S.; O'Connor, K.; Yigitcanlar, T. The implications of creative industries for regional outcomes. Int. J. Foresight. Innov. Policy 2009, 5, 44-64. [CrossRef]

18. Millar, C.C.; Ju Choi, C. Development and knowledge resources: A conceptual analysis. J. Knowl. Manag. 2010, 14, 759-776. [CrossRef]

19. Lönnqvist, A.; Käpylä, J.; Salonius, H.; Yigitcanlar, T. Knowledge that matters: Identifying regional knowledge assets of the Tampere region. Eur. Plan. Stud. 2014, 22, 2011-2029. [CrossRef]

20. Pancholi, S.; Yigitcanlar, T.; Guaralda, M. Urban knowledge and innovation spaces: Concepts, conditions and contexts. Asia Pac. J. Innov. Entrep. 2014, 8, 15-38.

21. Cowley, R.; Caprotti, F. Smart city as anti-planning in the UK. Environ. Plan. D 2018. [CrossRef]

22. Yigitcanlar, T.; Metaxiotis, K.; Carrillo, F.J. (Eds.) Building Prosperous Knowledge Cities: Policies, Plans and Metrics; Edward Elgar: Cheltenham, UK, 2012; ISBN 9780857936035.

23. Yin, R.K. Case Study Research, Design and Method; Sage: Newbury Park, CA, USA, 2009; ISBN 9781412960991.

24. Glaser, B.G.; Strauss, A.L. The Discovery of Grounded Theory; Aldine: Chicago, IL, USA, 1967; ISBN 0202302601.

25. Eisenhardt, K.M. Building theories from case study research. Acad. Manag. Rev. 1989, 14, 532-550. [CrossRef]

26. Carrillo, F.J.; Yigitcanlar, T.; García, B.; Lönnqvist, A. Knowledge and the City: Concepts, Applications and Trends of Knowledge-Based Urban Development; Routledge: New York, NY, USA, 2014; ISBN 1317931378.

27. Yigitcanlar, T.; Edvardsson, I.; Johannesson, H.; Kamruzzaman, M.; Ioppolo, G.; Pancholi, S. Knowledgebased development dynamics in less favoured regions: Insights from Australian and Icelandic university towns. Eur. Plan. Stud. 2017, 25, 2272-2292. [CrossRef] 
28. Hyde, K.F. Recognising deductive processes in qualitative research. Qual. Mark. Res. Int. J. 2000, 3, 82-90. [CrossRef]

29. Barufi, A.M.; Haddad, E.A.; Nijkamp, P. Industrial scope of agglomeration economies in Brazil. Ann. Reg. Sci. 2016, 56, 707-755. [CrossRef]

30. Barufi, A.M. Services that add value in the city: The rise of the modern economy in Brazil. Cities 2018, 78, 39-51. [CrossRef]

31. Mais, I.; de Carvalho, L.C.; Mohamed, A.; Hoffmann, M.G. The role of network relationships in innovation and internationalization of technology-based companies. RAI 2010, 7, 41. [CrossRef]

32. Capo, J.; Font, A.R.; Nadal, J.R. Dutch disease in tourism economies: Evidence from the Balearics and the Canary Islands. J. Sustain. Tour. 2007, 15, 615-627. [CrossRef]

33. Dalmarco, G.; Hulsink, W.; Blois, G.V. Creating entrepreneurial universities in an emerging economy: Evidence from Brazil. Technol. Forecast. Soc. Chang. 2018. [CrossRef]

34. Instituto Brasileiro de Geografia e Estatísticas (IBGE). Santa Catarina e Florianópolis; IBGE: Rio de Janeiro, Brazil, 2014.

35. Guerra, J.; Knabben, J.; Fernandez, F.; Bailey, C.; Barbosa, S.; Neiva, S. Reprint of: The adoption of strategies for sustainable cities: A comparative study between Newcastle and Florianópolis focused on urban mobility. J. Clean. Prod. 2017, 163, S209-S222. [CrossRef]

36. Google Maps. Available online: https://goo.gl/maps/DycdnkEoDev (accessed on 14 August 2018).

37. Michelmann, A.C. Franklin Cascaes, a Divulgação Turística de Florianópolis e a Invenção da 'Ilha da Magia'. Unpublished Bachelor Thesis, Federal University of Santa Catarina, Florianópolis, Brazil, 2017.

38. Azevedo, I.; Teixeira, C.; Teixeira, M. CELTA e MIDI Tecnológico: Um estudo de caso das incubadoras de Florianópolis. In Proceedings of the International Congress on Research \& Development, Curitiba, Brazil, 21-23 September 2016; pp. 347-363.

39. Bask, A.; Rajahonka, M. The role of environmental sustainability in the freight transport mode choice: A systematic literature review with focus on the EU. Int. J. Phys. Distrib. Manag. 2017, 47, 560-602. [CrossRef]

40. Sarimin, M.; Yigitcanlar, T. Towards a comprehensive and integrated knowledge-based urban development model: Status quo and directions. Int. J. Knowl.-Based Dev. 2012, 3, 175-192. [CrossRef]

41. Yin, R.K. Discovering the future of the case study: Method in evaluation research. Eval. Pract. 1994, 15, 283-290. [CrossRef]

42. Pancholi, S.; Yigitcanlar, T.; Guaralda, M. Governance that matters: Identifying place-making challenges of Melbourne's Monash Employment Cluster. J. Place Manag. Dev. 2017, 10, 73-87. [CrossRef]

43. Pancholi, S.; Yigitcanlar, T.; Guaralda, M. Attributes of successful place-making in knowledge and innovation spaces: Evidence from Brisbane's Diamantina knowledge precinct. J. Urban Des. 2018, 23, 693-711. [CrossRef]

44. Yin, R.K. Qualitative Research from Start to Finish; Guilford Press: London, UK, 2011; ISBN 1606239783.

45. Pancholi, S.; Yigitcanlar, T.; Guaralda, M. Place making in knowledge and innovation spaces: The Australia experience. Technol. Forecast. Soc. Chang. 2017. [CrossRef]

46. Yigitcanlar, T. Position paper: Benchmarking the performance of global and emerging knowledge cities. Expert Syst. Appl. 2014, 41, 5549-5559. [CrossRef]

47. Pancholi, S.; Yigitcanlar, T.; Guaralda, M. Societal integration that matters: Place making experience of Macquarie Park Innovation District, Sydney. City Cult. Soc. 2018, 13, 13-21. [CrossRef]

48. Constantinou, C.S.; Georgiou, M.; Perdikogianni, M. A comparative method for themes saturation (CoMeTS) in qualitative interviews. Qual. Res. 2017, 17, 571-588. [CrossRef]

49. Lenzi, M.H. A Invenção de Florianópolis Como Cidade Turística: Discursos, Paisagens e Relações de Poder. Unpublished Doctoral Thesis, University of São Paulo, São Paulo, Brazil, 2016.

50. Pereira, E.M. A importância de conceitos modernistas no planejamento urbano de Florianópolis. Seminário de Historia da Cidade e do Urbanismo 2000, 6, 1-15.

51. Machado, E.V. Florianópolis: Um Lugar em Tempo de Globalização. Unplublished Doctoral Thesis, Federal University of Santa Catarina, Florianópolis, Brazil, 2000.

52. Barreto, M.; Burgos, R.; Frenkel, D. Turismo, Políticas Públicas e Relações Internacionais; Papirus: Campinas, Brazil, 2003; ISBN 8530807154.

53. Oliveira, A.P. A História do Turismo em Florianópolis Narrada por Quem a Vivenciou (1950-2010); Palavracom Editora: Florianópolis, Brazil, 2011; ISBN 9788564034051. 
54. De Luca Filho, V. A Geografia das Feiras de Negócios em Santa Catarina: Origem, Evolução e Dinâmica das Transformações. Unpublished Doctoral Thesis, Federal University of Santa Catarina, Florianópolis, Brazil, 2014.

55. Santos, F.M.; Pereira, R.M. A rede hoteleira no núcleo urbano central de Florianópolis: Expansão urbana e turismo. In Proceedings of the IV Mercosur Tourism Research Seminar, Caxias do Sul, Brazil, 7-8 July 2006; pp. 1-15.

56. Paulilo, M.I. Maricultura e território em Santa Catarina, Brasil. Geosul 2002, 17, 87-112.

57. Azevedo, I.; Teixeira, C. Florianópolis: Uma análise evolutiva do desenvolvimento do desenvolvimento inovador da cidade a partir do seu ecossistema de inovação. REAVI 2017, 6, 108-121. [CrossRef]

58. Sabatini-Marques, J.; Yigitcanlar, T.; Costa, E. Incentivizing innovation: A review of the Brazilian federal innovation support programs. Asia Pac. J. Innov. Entrep. 2015, 9, 31-56.

59. Xavier, M. Polo Tecnológico de Florianópolis: Origem e Desenvolvimento; Insular: Florianópolis, Brazil, 2010; ISBN 9788574744957.

60. Esmaeilpoorarabi, N.; Yigitcanlar, T.; Guaralda, M. Place quality and urban competitiveness symbiosis? A position paper. Int. J. Knowl.-Based Dev. 2016, 7, 4-21. [CrossRef]

61. Yigitcanlar, T.; Sabatini-Marques, J.; Kamruzzaman, M.; Camargo, F.; Costa, E.; Ioppolo, G.; Palandi, F. Impact of funding sources on innovation: Evidence from Brazilian software companies. RED Manag. 2018, 48, 460-484. [CrossRef]

62. Yigitcanlar, T.; Sabatini-Marques, J.; Costa, E.M.; Kamruzzaman, M.; Ioppolo, G. Stimulating technological innovation through incentives: Perceptions of Australian and Brazilian firms. Technol. Forecast. Soc. Chang. 2017. [CrossRef]

63. Techflier. 9 Tech Startups from Florianópolis You Need to Know about in 2016. Available online: https: / / www.techflier.com/2016/09/03/9-tech-startups-from-florianopolis-you-need-to-know-about-in-2016/ (accessed on 6 September 2018).

64. Tarachucky, L. Sistematização da Aplicação do Brand DNA Process No Design de Marca de Cidades Criativas: Caso Projeto Rota da Inovação. Unpublished Master Thesis, Federal University of Santa Catarina, Florianópolis, Brazil, 2015.

65. Google Maps. Available online: https://goo.gl/maps/EiLAFigrR1K2 (accessed on 14 August 2018).

66. Endeavor Brazil. Índice de Cidades Empreendedoras. Available online: http://info.endeavor.org.br/ice2017 (accessed on 28 June 2018).

67. Ueno, A. A Concepção de um Modelo de Empreendedorismo Inovador Baseado em Conhecimento: Um Estudo de Caso do Programa Sinapse da Inovação. Unpublished Master Thesis, Federal University of Santa Catarina, Florianópolis, Brazil, 2011.

68. Depine, A.C. Fatores de Atração e Retenção da Classe Criativa: O Potencial de Florianópolis Como Cidade Humana Inteligente. Unpublished Master Thesis, Federal University of Santa Catarina, Florianópolis, Brazil, 2016.

69. Fernandes, E. The legalisation of favelas in Brazil: Problems and prospects. Third World Plan. Rev. 2000, 22, 167. [CrossRef]

70. Prefeitura Municipal de Florianópolis (PMF). Municipal Plan of Housing of Social Interest of Florianópolis; PMF: Florianópolis, Brazil, 2012.

71. Prefeitura Municipal de Florianópolis (PMF). Florianópolis Sustainability Action Plan; PMF: Florianópolis, Brazil, 2017.

72. Instituto Brasileiro de Geografia e Estatísticas (IBGE). Florianópolis Panorama. Available online: https: / / cidades.ibge.gov.br/brasil/sc/florianopolis/panorama (accessed on 6 September 2018).

73. Prefeitura Municipal de Florianópolis (PMF). Florianópolis Urban Growth Study; PMF: Florianópolis, Brazil, 2017.

74. Prefeitura Municipal de Florianópolis (PMF). Florianópolis Mitigation and Climate Change Study; PMF: Florianópolis, Brazil, 2017.

75. Oliveira-Musse, J.; Homrich, A.S.; Mello, R.; Carvalho, M.M. Applying backcasting and system dynamics towards sustainable development: The housing planning case for low-income citizens in Brazil. J. Clean. Prod. 2018, 193, 97-114. [CrossRef] 
76. ND Online. SC-401 em Números: A Rodovia de Florianópolis é a Líder em Mortes e Acidentes. Available online: https: / / ndonline.com.br/florianopolis/especiais/sc-401-em-numeros-a-rodovia-de-florianopolise-a-lider-em-mortes-e-acidentes (accessed on 1 August 2018).

77. Yigitcanlar, T.; Kamruzzaman, M. Investigating the interplay between transport, land use and the environment: A review of the literature. Int. J. Environ. Sci. Technol. (Tehran) 2014, 11, 2121-2132. [CrossRef]

78. Yigitcanlar, T.; Kamruzzaman, M.; Buys, L.; Ioppolo, G.; Sabatini-Marques, J.; Costa, E.; Yun, J. Understanding 'smart cities': Intertwining development drivers with desired outcomes in a multidimensional framework. Cities 2018, 81, 145-160. [CrossRef]

79. Yigitcanlar, T. Smart cities: An effective urban development and management model? Aust. Plan. 2015, 52, 27-34. [CrossRef]

80. Metaxiotis, K.; Carrillo, J.; Yigitcanlar, T. (Eds.) Knowledge-Based Development for Cities and Societies: An Integrated Multi-Level Approach; IGI Global: Hersey, PA, USA, 2010; ISBN 1615207228.

81. Bridges, A. Leveraging Amenity-Led Growth and Collective Action for Sustainable Development in Florianópolis, 1965-2016. Unpublished Doctoral Thesis, Rutgers University, New Brunswick, NJ, USA, 2017.

82. Scherer, M.E.; Asmus, M.L. Ecosystem-based knowledge and management as a tool for integrated coastal and ocean management: A Brazilian initiative. J. Coast. Res. 2016, 75, 690-694. [CrossRef]

83. Prefeitura Municipal de Florianópolis (PMF). Floripa Se Liga Na Rede; PMF: Florianópolis, Brazil, 2013.

84. Figueiroa, A.; Scherer, M. Para onde estamos indo? Uma avaliação do plano diretor do Município de Florianópolis para o entorno da Estação Ecológica de Carijós. Desenvolvimento e Meio Ambiente 2016, 38, 283-301. [CrossRef]

85. Bastos, G. Análise Financeira das Pescarias de Pequena escala No Município de Florianópolis. Unpublished Doctoral Thesis, University of São Paulo, São Paulo, Brazil, 2009.

86. Stahelin, G.D.; Fiedler, F.N.; Lima, E.P.; Sales, G.; Wanderlinde, J. Projeto Tamar's station in Florianópolis, State of Santa Catarina, Southern Brazil. Mar. Turt. Newslett. 2012, 133, 23.

87. Goonetilleke, A.; Yigitcanlar, T.; Ayoko, G.A.; Egodawatta, P. Sustainable Urban Water Environment: Climate, Pollution and Adaptation; Edward Elgar: Cheltenham, UK, 2014; ISBN 1781004641.

88. Afonso, O.; Monteiro, S.; Thompson, M. A growth model for the quadruple helix. J. Bus. Econ. Manag. 2012, 13, 849-865. [CrossRef]

89. Yigitcanlar, T.; Bulu, M. Dubaization of Istanbul: Insights from the knowledge-based urban development journey of an emerging local economy. Environ. Plan. A 2015, 47, 89-107. [CrossRef]

90. Yigitcanlar, T.; Dur, F. Making space and place for knowledge communities: Lessons for Australian practice. Aust. J. Reg. Stud. 2013, 19, 36-63.

91. Pancholi, S.; Yigitcanlar, T.; Guaralda, M. Place making facilitators of knowledge and innovation spaces: Insights from European best practices. Int. J. Knowl.-Based Dev. 2015, 6, 215-240. [CrossRef]

92. Zhang, Y.S.; Zou, S.M. The governance mechanisms in innovation ecosystem of hi-tech enterprises. Stud. Sci. Sci. 2010, 5, 020.

93. Yigitcanlar, T.; Inkinen, T. Geographies of Disruption: Place Making for Innovation in the Age of Knowledge Economy; Springer: New York, NY, USA, 2019; ISBN 9783030032067.

94. Yigitcanlar, T.; Kamruzzaman, M. Does smart city policy lead to sustainability of cities? Land Use Policy 2018, 73, 49-58. [CrossRef]

95. Dutta, S.; Lanvin, B.; Wunsch-Vincent, S. The Global Innovation Index 2018: Energizing the World with Innovation; Cornell University: Ithaca, NY, USA, 2018; ISBN 9791095870098.

96. Lara, A.P.; Da Costa, E.M.; Furlani, T.Z.; Yigitcanlar, T. Smartness that matters: Towards a comprehensive and human-centred characterisation of smart cities. J. Open Innov. Technol. Mark. Complex. 2016, 2, 8. [CrossRef]

97. Trindade, E.; Hinnig, M.; Costa, E.; Sabatini-Marques, J.; Bastos, R.; Yigitcanlar, T. Sustainable development of smart cities: A systematic review of the literature. J. Open Innov. Technol. Mark. Complex. 2017, 3, 11. [CrossRef]

98. Lara, A.P.; Marques, J.S.; Santos, N.; Costa, E.M. Projeto Florip@ 21: A construção de uma região inteligente na cidade de Florianópolis, Brasil. In Proceedings of the XV Latin Iberian-American Congress on Management of Technology, Porto, Portugal, 27-31 October 2013; pp. 1673-1691.

99. Lorenzetti, J.; de Lima Trindade, L.; Pires de Pires, D.E.; Souza Ramos, F.R. Tecnologia, inovação tecnológica e saúde: Uma reflexão necessária. Texto \& Contexto Enfermagem 2012, 21, 432-439. 
100. Martins, C. O Papel das Incubadoras de Empresas do Polo Tecnológico de Florianópolis No Desenvolvimento do Processo de Empreendedorismo Inovador. Unpublished Master Thesis, Universidade do Sul de Santa Catarina, Florianópolis, Brazil, 2013.

101. Sarquis, A.B.; Fiates, G.G.; Hahn, A.K.; Cavalcante, F.R. Empreendedorismo inovador no polo tecnológico de Florianópolis. REEN 2014, 7, 228-255. [CrossRef]

102. Gaspar, J.V.; Menegazzo, C.; Fiates, J.E.; Teixeira, C.S.; Gomes, L.S. A revitalização de espaços urbanos: O case do Centro Sapiens em Florianópolis. Revista Livre de Sustentabilidade e Empreendedorismo 2017, 29, $183-205$.

103. Menezes, A.G.; Lezana, Á.G.; de Abreu-Ronconi, L.F.; de Oliveira-Menezes, E.C.; de Melo, É.N. A pesquisa-ação como estratégia de avaliação da inovação social: Estudo de uma entidade educacional do município de Florianópolis. NAVUS Revista de Gestão e Tecnologia 2016, 6, 93-105. [CrossRef]

2018 by the authors. Licensee MDPI, Basel, Switzerland. This article is an open access article distributed under the terms and conditions of the Creative Commons Attribution (CC BY) license (http:/ / creativecommons.org/licenses/by/4.0/). 